\title{
Disposal R\&D in the Used Fuel Disposition Campaign: A Discussion of Opportunities for Active International Collaboration
}

\author{
Jens Birkholzer \\ Lawrence Berkeley National Laboratory (LBNL) \\ Technical Lead for International Activities \\ Used Fuel Disposition Campaign (UFDC) \\ DOE Office of Nuclear Energy (NE)
}

June 2011

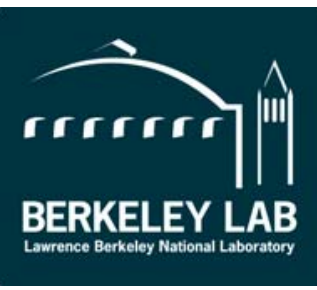

This work was supported in part by the U.S. Department of Energy and LBNL under Contract No. DE-AC02-05CH11231. 


\section{Table of Contents}

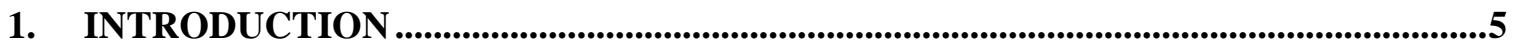

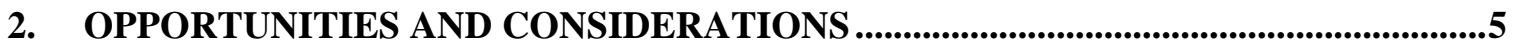

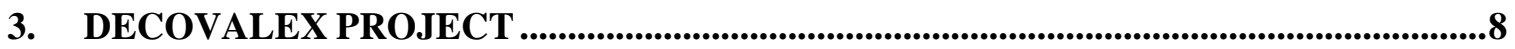

3.1 SEALEX Experiment at the Tournemire URL, France (Focus: EBS)............... 11

3.2 MB Test at Mont Terri URL, Switzerland (Focus: NBS) ................................. 13

3.3 HE-E Heater Test at Mont Terri URL, Switzerland (Focus: EBS and its

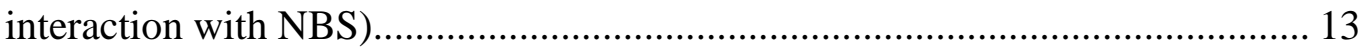

3.4 Bedrichov Tunnel Experiment, Czech Republic (Focus: NBS)......................... 14

3.5 THMC Processes in Single Fractures (Focus: NBS) ...................................... 15

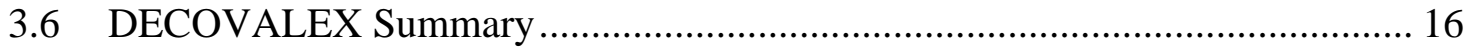

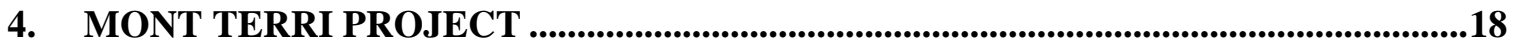

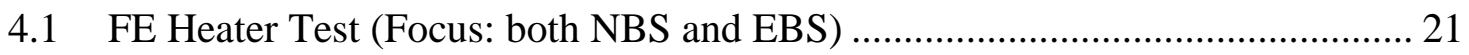

4.2 Mont Terri Summary ............................................................................. 22

5. COLLOID FORMATION AND MIGRATION PROJECT ........................................24

5.1 Colloid-Facilitated Radionuclide Tracer Test (Focus: NBS) ............................. 27

5.2 Radionuclide-Doped Bentonite Plug Transport Experiment (Focus: both NBS

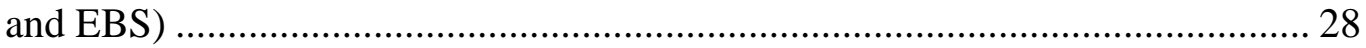

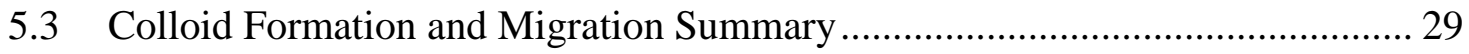

6. OTHER ACTIVE COLLABORATION OPPORTUNITIES .......................................30

6.1 Experiments at HADES URL in Mol, Belgium ................................................ 30

6.2 Experiments at Grimsel Test Site, Switzerland................................................. 33

6.3 Experiments at Äspö Hard Rock Laboratory, Sweden ...................................... 34

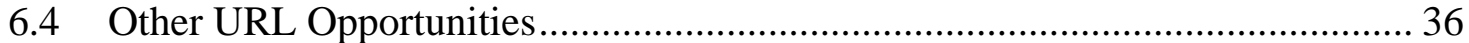

6.5 Alternative Options for DECOVALEX, Mont Terri and CFM Participation..... 36

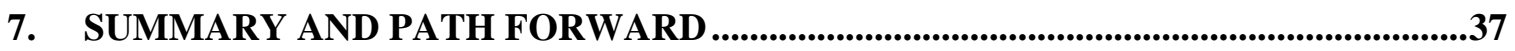

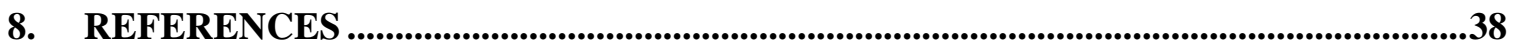

\section{List of Figures}

Figure 3-1. Schematic setup of mini-tunnel with seal core and instrumentation (left); view from gallery after core emplacement (right) (from Barnichon, 2011) ..................... 12

Figure 3-2. Planned experiments and schedule (from Barnichon, 2011)....................... 12

Figure 3-3. Geological cross section of the Tournemire site, South France (from Barnichon, 2011).

Figure 3-4. Schematic setup of MB Mine-by test at Mont Terri showing location of selected boreholes for piezometer, extensometer, and inclinometer data (from Vietor et al., 2011)

Figure 3-5. Schematic setup of HE-E heater test at Mont Terri and photo of micro-tunnel (from Garitte et al., 2011) 14

Figure 3-6. Bohemian granitic massif in Czech Republic and Water Inflow Evidence in the Bedrichov Tunnel (from Hokr and Slovak, 2011). 15 
Figure 3-7. Results showing THMC behavior effects in a single fracture exposed to different external temperatures and varying stress conditions (from Polak et al., 2003) . 16

Figure 4-1. Summary schematic of the Mont Terri URL with side galleries and drifts for testing. Three specific experiments of relevance to UFDC are highlighted (based on Garitte, 2010)

Figure 4-2. Plan view of Mont Terri with locations of Phase 16 experiments, status September 2010 (from Vietor, 2011). 20

Figure 4-3. Plan view of experiment setup and borehole layout (from Garitte, 2010).... 21

Figure 4-4. Side view of experiment setup and borehole layout (from Garitte, 2010).... 22

Figure 5-1. Tunnel packer system used to isolate the MI shear zone. Small disks with tubing issuing from them (inside yellow packer) are "surface packers" that seal the tunnel wall and collect water from inflow points. Tunnel diameter is 3.5 meters. 25

Figure 5-2. Tracer flow pathways and flow distances in the MI shear zone in all CRR and CFM tracer tests (2001-present). All boreholes penetrating the shear zone in the vicinity of the tunnel packer system are shown, with numbers inside boxes indicating head measurements (in meters) during a recent (2010) tracer test from CFM 06.002 to the "Pinkel" surface packer.... 26

Figure 5-3. Schematic setup drawing of bentonite plug emplacement and bentonite swelling/erosion and colloid transport experiment. Note that the boreholes between CFM 06.002 and the main tunnel (green and red) will likely not be drilled. .................. 28

Figure 6-1. Layout of the HADES URL in Mol, Belgium ......................................... 30

Figure 6-2. Layout of the PRACLAY In-Situ Experiment (from Li, 2011)................... 31

Figure 6-3. Configuration of boreholes for pressure, stress, displacement, and water chemistry measurements (from Li, 2011).

Figure 6-4. Photo on left shows hydraulic seal from the outside, with an access hole to the right which soon will be closed. Photo on right was taken from access hole into the heater gallery section, which is currently being backfilled (from Birkholzer, 2011) ....... 32

Figure 6-5. Schematic of CP1 diffusion experiment (from Maes et al., 2011)................ 32

Figure 6-6. Schematic picture of repository seal design for GAST experiment (from

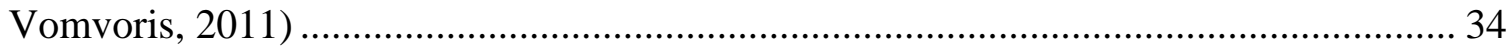

Figure 6-7. Layout of Äspö URL and location of main experiments ........................... 35

Figure 6-8. LASGIT experiment at Äspö (from Cuss, 2010) ......................................... 35

\section{List of Tables}

Table 2-1. Summary of UNF and HLW Management Programs in Other Countries........ 6

Table 3-1. Proposed Modeling Test Cases for DECOVALEX-2015 (from Jing and

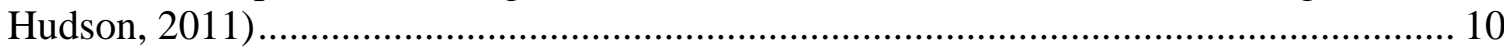

Table 4-1. List of experiments being conducted at Mont Terri, from 1996 through 2005 (from Bossart and Thury, 2007). 


\section{INTRODUCTION}

For DOE's Used Fuel Disposition Campaign (UFDC), international collaboration is a beneficial and cost-effective strategy for advancing disposal science with regards to multiple disposal options and different geologic environments. While the United States disposal program focused solely on Yucca Mountain tuff as host rock over the past decades, several international programs have made significant progress in the characterization and performance evaluation of other geologic repository options, most of which are very different from the Yucca Mountain site in design and host rock characteristics. Because Yucca Mountain was so unique (e.g., no backfill, unsaturated densely fractured tuff), areas of direct collaboration with international disposal programs were quite limited during that time.

The decision by the U.S. Department of Energy to no longer pursue the disposal of highlevel radioactive waste and spent fuel at Yucca Mountain has shifted UFDC's interest to disposal options and geologic environments similar to those being investigated by disposal programs in other nations. Much can be gained by close collaboration with these programs, including access to valuable experience and data collected over recent decades. Such collaboration can help to efficiently achieve UFDC's long-term goals of conducting "experiments to fill data needs and confirm advanced modeling approaches" (by 2015) and of having a "robust modeling and experimental basis for evaluation of multiple disposal system options” (by 2020).

This report discusses selected opportunities of active international collaboration, with focus on both Natural Barrier System (NBS) and Engineered Barrier System (EBS) aspects and those opportunities that provide access to field data (and respective interpretation/modeling) or allow participation in ongoing field experiments. This discussion serves as a basis for the DOE/NE-53 and UFDC planning process for FY12 and beyond.

\section{OPPORTUNITIES AND CONSIDERATIONS}

Internationally, geologic disposal programs are at different maturation states, ranging from essentially "no progress" to selected sites and pending license applications to regulators. Table 2-1 summarizes the status of used nuclear fuel (UNF) and high-level waste (HLW) management programs in several countries. The opportunity exists to collaborate at different levels, ranging from providing expertise to those countries "behind" the U.S. to obtaining access to information and expertise from those countries with mature programs (Used Fuel Disposition Campaign International Activities Implementation Plan, FCR\&D-USED-2011-000016 REV 0, November 2010 [Nutt, 2010]).

As to the possible types of international involvement, one may distinguish between two broad categories. The first category comprises participation in multinational or bilateral organizations, working groups, or committees, and typically involves high-level information exchanges, expert panels, review functions, training and education, etc. 
Recent or ongoing UFDC (or NE-53) activities in this area have been summarized in Used Fuel Disposition Campaign International Activities Implementation Plan (FCR\&DUSED-2011-000016 REV 0, November 2010 [Nutt, 2010]). A few selected examples include multinational activities such as under IAEA (e.g., review activities, conference participation, education within the International Training Center, ITC, ...), OECD/NEA (e.g., participation in annual meetings, Integration Group for the Safety Case membership, R\&D on NEA Thermodynamic Database,...), EDRAM (International Association for Environmentally Safe Disposal of Radioactive Waste), or bilateral agreements such as PUNT (U.S.-China Peaceful Uses of Nuclear Energy) and NEAP (U.S.-Japan Nuclear Energy Action Plan). UFDC will continue participation and/or support of many of the international activities discussed above, and may need to expand on certain activities, but will also need to be selective in its choices, to further those opportunities that are of most benefit to the campaign.

Table 2-1. Summary of UNF and HLW Management Programs in Other Countries

\begin{tabular}{|c|c|c|c|c|c|c|}
\hline Country & $\begin{array}{l}\text { Material to be } \\
\text { Disposed }\end{array}$ & $\begin{array}{l}\text { Centralized } \\
\text { Storage }\end{array}$ & Geologic Environments & URL & Site-Selection & $\begin{array}{l}\text { Anticipated Start of Repository } \\
\text { Operations }\end{array}$ \\
\hline Finland & SNF & & $\begin{array}{l}\text { Granite, Gneiss, Grandiorite, } \\
\text { Migmatite }\end{array}$ & ONKALO (Granite) & Site at Olkiluoto Selected & 2020 \\
\hline Sweden & SNF & $\begin{array}{c}\text { CLAB - } \\
\text { Oskarshamn }\end{array}$ & Granite & Aspo (Granite) & Site at Osthammar Selected & 2023 \\
\hline France & HLW and ILW & & Argillite and Granite & Bure (Argillite) & Site near Bure Selected & 2025 \\
\hline Belgium & HLW & & Clay/Shale & Mol (clay) & Not Initiated & $\sim 2040$ \\
\hline China & HLW & & Granite & & $\begin{array}{c}\text { Preliminary Investigations Underway } \\
\text { Beishan in Gobi Desert }\end{array}$ & $\sim 2050$ \\
\hline Switzerland & HLW & $\begin{array}{l}\text { Wulenlingen } \\
\text { (ZWILAG) }\end{array}$ & Clay and Granite & $\begin{array}{l}\text { Mont Terri (Clay) } \\
\text { Grimsel (Clay) }\end{array}$ & Initiated & No sooner than 2040 \\
\hline Japan & HLW & & Granite and Sedimentary & $\begin{array}{c}\text { Mizunami (Granite) } \\
\text { Hornonobe } \\
\text { (Sedimentary) }\end{array}$ & Initiated & No Decision Made \\
\hline Canada & SNF & & Granite and Sedimentary & $\begin{array}{c}\text { Pinawa (Granite) - } \\
\text { being decommissioned }\end{array}$ & Initiated & No Decision Made \\
\hline United Kingdom & HLW and ILW & & Undecided & & Initiated & No Decision Made \\
\hline Germany & $\begin{array}{l}\text { HLW, SNF, heat } \\
\text { generating ILW }\end{array}$ & $\begin{array}{l}\text { Gorleben and } \\
\text { Ahaus }\end{array}$ & Salt & Gorleben (Salt) & On Hold & No Decision Made \\
\hline Republic of Korea & SNF & Envisioned & Granite & $\begin{array}{l}\text { Korea Underground } \\
\text { Research Tunnel } \\
\text { (Granite, Shallow) }\end{array}$ & Not Initiated & No Decision Made \\
\hline Spain & No Decision Made & $\begin{array}{l}\text { Siting Process } \\
\text { Initiated }\end{array}$ & Granite, Clay, Salt & & Not Initiated & No Decision Made \\
\hline
\end{tabular}

The second category involves active R\&D collaboration of UFDC researchers within international projects or programs in close collaboration with multinational scientists. By active $R \& D$, we mean here that UFDC scientists work together closely with international scientists on concrete research projects relevant to both sides. Such active collaboration would provide direct access to information, data, and expertise on various disposal options and geologic environments that have been collected over the past decades. Many international programs have operating underground research laboratories (URLs) in clay/shale, granite, and salt environments, in which relevant field experiments have been and are being conducted. These are typically generic, not site-specific laboratories; i.e., they are not intended to be later used for emplacement of waste.

Depending on the type of collaboration, UFDC researchers may be able to participate in planning, conducting, and interpreting experiments in these generic laboratories, and thereby get early access to field studies without having in situ research facilities in the U.S. We consider such active R\&D activities to be most beneficial to UFDC, to help 
efficiently achieve its long-term goals of conducting "experiments to fill data needs and confirm advanced modeling approaches" (by 2015) and of having a "robust modeling and experimental basis for evaluation of multiple disposal system options” (by 2020). Advancing opportunities for active international collaboration will be the primary focus of UFDC's international activities in the next few years. (Obviously, the first category of international involvement discussed above is important in helping identify and facilitate avenues of active R\&D collaboration; it is thus important that UFDC or NE-53 continue participation in multinational or bilateral organizations such as IAEA, or OECD/NEA.)

Active collaboration can be achieved under different working models. One straightforward option is informal peer-to-peer interaction with international R\&D organizations. Several UFDC scientists, most of which are associated with DOE's national laboratories, have close relationships with their international counterparts, resulting from workshops and symposia meetings, or from active R\&D collaboration outside of UFDC's scope. Continued UFDC support for participation of UFDC researchers in relevant international workshops, meetings, and symposia will help to foster discussion and expand such relationships.

Other working models for active collaboration may require formal agreement and sometimes financial commitment before $R \& D$ collaboration can take place. It is advisable that such agreements with international organizations/partners should be exercised by DOE, rather than by the UFDC or individual DOE national laboratories. Valuable multinational and multi-partner initiatives that promote active R\&D in nuclear waste disposal science and that require DOE "membership" are the DECOVALEX Project, the Mont Terri Project, and the Colloid Formation and Migration Project, all of which are further discussed below. A decision as to whether DOE should become a formal "member" in such international agreements is urgent because it strongly affects the UFDC planning process for FY12 and beyond. Instead of multi-partner initiatives, DOE national laboratories may also directly participate in specific projects conducted by individual international disposal programs. The latter may or may not require formal bilateral agreements.

The following sections describe in more detail opportunities for active research with international disposal programs. The focus here is on such opportunities that provide access to field data (and respective interpretation/modeling) and/or may allow participation in ongoing and planned field experiments. Of these opportunities, we describe in this report near-term options related to the NBS and the EBS work packages of the UFDC. As to the NBS aspects, we focus on clay/shale and crystalline rock collaboration opportunities. (There is only one URL in salt host rock outside of the U.S., near Gorleben in Germany. Due to political resistance, research activities at Gorleben had been suspended for about a decade; the research program on salt has just recently been restarted in Germany.) As to the EBS, we look mostly into buffer/backfill and seal behavior, and the interaction of these materials with other EBS components and the surrounding host rock. Additional detail on any of the experimental efforts and initiatives discussed below can be provided upon request. 
The benefit of international collaboration needs to be evaluated in the context of the open R\&D issues that can be addressed through collaborative scientific activities. Open R\&D issues with respect to NBS behavior are summarized in previous progress reports (e.g., Natural System Evaluation and Tool Development - FY10 Progress Report, August 2010 [Wang, 2010]); specific R\&D issues related to clay/shale host rock are discussed, for example, in Tsang et al. (2011). EBS-related R\&D items have also been considered in previous progress reports (e.g., Jove-Colon et al., 2010). All R\&D gaps identified in these reports have been evaluated in consideration of their importance to the safety case in a recently conducted roadmap exercise (Used Fuel Disposition Campaign Disposal Research and Development Roadmap, FCRD-USED-2011-000065 Rev 0, March 2011; Tables 7 and 8; [Nutt, 2011]).

Section 3 through 5 describe the DECOVALEX Project, the Mont Terri Project, and the Colloid Formations and Migration Project, respectively, all of which are international initiatives requiring formal DOE "membership". Each section provides information on cost and benefits, the mode of participation, and the key research gaps addressed (with tight link to roadmap and FEPs importance ranking; using the Used Fuel Disposition Campaign Disposal Research and Development Roadmap, FCRD-USED-2011-000065 Rev 0, March 2011 [Nutt, 2011]). Section 6 describes other options for international collaboration; i.e., options that may not require formal "membership", but may rather be facilitated via direct informal or semi-formal agreements between national laboratories and international partners.

\section{DECOVALEX PROJECT}

The DECOVALEX Project is a unique international research collaboration for advancing the understanding and mathematical modeling of coupled thermo-hydro-mechanical (THM) and thermo-hydro-chemical (THC) processes in geological systems. DECOVALEX is an acronym for "Development of Coupled Models and their Validation against Experiments". Starting in 1992, the project has made important progress and played a key role in the development of numerical modeling of coupled processes in fractured rocks and buffer/backfill materials. The project has been conducted by research teams supported by a large number of radioactive-waste-management organizations and regulatory authorities, including those of Canada, China, Finland, France, Japan, Germany, Spain, Sweden, UK, South Korea, Czech Republic, and the USA. Through this project, in-depth knowledge has been gained of coupled THM and THMC processes associated with nuclear waste repositories, as well as numerical simulation models for their quantitative analysis. The knowledge accumulated from this project, in the form of a large number of research reports and international journal and conference papers in the open literature, has been applied effectively in the implementation and review of national radioactive-waste-management programs in the participating countries. A good overview of the project is given in Tsang et al. (2009).

The DECOVALEX Project is typically conducted in separate 3-4 year project phases. Each phase features a small number (typically three to six) modeling test cases of importance to radioactive waste disposal. Many test cases are laboratory and field 
experiments that have been conducted by one of the project partners and are then collectively studied and modeled by DECOVALEX participants. Numerical modeling of these test cases can assist both to interpret the test results and to test the models used. Over the years, a number of large-scale, multiyear field experiments have been studied within the project (e.g., the Kamaishi THM Experiment, FEBEX, and the Yucca Mountain drift-scale heater test). Thus, the project provides access to valuable technical data and expertise to DECOVALEX partner organizations; this is particularly useful in disposal programs that are starting their research on certain disposal or repository environments and have no URLs. DECOVALEX has a modeling focus, but with tight connection to experimental data.

To participate in a given DECOVALEX phase, interested parties—such as waste management organizations or regulatory authorities—need to formally join the project and pay an annual fee that covers the cost of administrative and technical matters. In addition to this fee, participating organizations provide funding to their own research teams to work on some or all of the problems defined in the project phase. Representatives from the funding organizations form a Steering Committee that collectively directs all project activities.

DOE was a DECOVALEX partner for several project phases, but decided to drop out in 2007 with the increasing focus on the license application for Yucca Mountain. Now that the U.S. R\&D program has shifted to other disposal options and geologic environments, a renewed DOE engagement with DECOVALEX would provide UFDC researchers access to relevant field data from international programs and allow them to work collaboratively with international scientists on analyzing and modeling these data. The next DECOVALEX phase, referred to as DECOVALEX-2015, will start in early 2012. A planning session for this next DECOVALEX phase was held in a recent workshop in Helsinki (April 2011), and several modeling test cases involving experimental data were proposed by prospective funding organizations (Table 3-1).

1. SEALEX Experiment: A long term test of the hydraulic (sealing) performance of a swelling bentonite core ( $5 \mathrm{~m}$ long) in a mini tunnel $(60 \mathrm{~cm}$ diameter) at the Tournemire URL in France, proposed by ISRN (France)

2. Mine-by (MB) Test: HM test studying pore pressure and stress evolution during excavation, at the Mont Terri URL, proposed by NAGRA (Switzerland)

3. HE-E Heater Test: Studies of bentonite/rock interaction to evaluate sealing and clay barrier performance, in a micro-tunnel at the Mont Terri URL, proposed by ENRESA (Spain)

4. Bedrichov Tunnel Experiment: Interpretation of inflow patterns and tracer transport behavior in a fractured granite, proposed by NAWRA (Czech Republic)

5. Possible revisits of past DECOVALEX phases for the purpose of identifying potential tasks containing unsolved but important issues, tentatively proposed by CEA (France)

6. THMC Processes in Single Fractures: Modeling of laboratory experiments on mechano-chemical impacts on fracture flow, tentatively proposed by KAERI/LBNL (South Korea/USA) 
Table 3-1. Proposed Modeling Test Cases for DECOVALEX-2015 (from Jing and Hudson, 2011)

\begin{tabular}{|c|c|c|c|c|c|c|}
\hline Task No. & 1 & 2 & 3 & 4 & 5 & 6 \\
\hline Task Title & Sealex & Mine-By & HE-E Heater Test & Bedrichov Tunnel & $\begin{array}{c}\text { Past D-Tasks (FEBEX, BMTl, } \\
\text { BMT3) }\end{array}$ & THMC Fracture \\
\hline Proponent & IRSN & NAGRA & PEBS & RAWRA & D-2011 & LBNL \\
\hline $\begin{array}{l}\text { Main } \\
\text { concern }\end{array}$ & $\begin{array}{l}\text { Engineering Barrier } \\
\text { System, EBS-rock } \\
\text { interaction }\end{array}$ & $\begin{array}{l}E D Z \text { and } \mathrm{HM} \\
\text { response of rock } \\
\text { to excavation }\end{array}$ & $\begin{array}{l}\text { EBS \& EBS-rock } \\
\text { interaction }\end{array}$ & $\begin{array}{l}\text { Flow \& transport in } \\
\text { fractured crystalline rocks }\end{array}$ & $\begin{array}{c}\text { EBS, EBS-rock interaction (FEBEX, } \\
\text { BMT1, BMT3 (D_THM); } \\
\text { Long term property change (BMT3, } \\
\text { D_THC) }\end{array}$ & Fundamental study \\
\hline $\begin{array}{l}\text { Related to } \\
\text { which } \\
\text { repository } \\
\text { develop-m } \\
\text { ent stage }\end{array}$ & $\begin{array}{l}\text { Excavation, sealing } \\
\text { \& post-closure }\end{array}$ & Excavation & Sealing \& post-closure & $\begin{array}{c}\text { Site } \\
\text { Characterization and safety } \\
\text { assessment (water flow } \\
\text { and transport) }\end{array}$ & EBS \& post-closure & $\begin{array}{l}\text { Site characterisation } \\
\text { through to safety } \\
\text { assessment }\end{array}$ \\
\hline Processes & THMC & $\mathrm{HM}$ & THM & MHC & THM, THC & THMC \\
\hline Test time & $\begin{array}{l}2011-2015 \text { and } \\
\text { beyond }\end{array}$ & Completed & 2011-2015 and beyond & $\begin{array}{c}\text { Basic characterisation } \\
\text { completed, tracer tests } \\
\text { planned }\end{array}$ & $\begin{array}{l}\text { Completed in earlier DECOVALEX } \\
\text { phases but data will be re-analysed }\end{array}$ & $\begin{array}{l}\text { Data obtained, } \\
\text { published data \& } \\
\text { literature support }\end{array}$ \\
\hline Host rock & Clay & Clay & Clay & Granite & $\begin{array}{c}\text { Granite (FEBEX, BMT1, BMT3 } \\
(\text { D_THM)), Tuff (BMT3(D_THC)) }\end{array}$ & $\begin{array}{l}\text { Granite and other } \\
\text { hard rocks }\end{array}$ \\
\hline Test site & Tournemire, France & $\begin{array}{l}\text { Mont Terri, } \\
\text { Switzerland }\end{array}$ & $\begin{array}{l}\text { Mont Terri, } \\
\text { Switzerland }\end{array}$ & Czech Republic & $\begin{array}{l}\text { Grimsel, Switzerland; Yucca Mountain, } \\
\text { USA; Kamaishi, Japan }\end{array}$ & Laboratory tests \\
\hline $\begin{array}{l}\text { Relevance } \\
\text { to other } \\
\text { rock types }\end{array}$ & $\begin{array}{c}\text { Argillaceous but } \\
\text { applies to all types } \\
\text { of host rocks using } \\
\text { EBS }\end{array}$ & $\begin{array}{l}\text { Specific to } \\
\text { argillaceous } \\
\text { rock }\end{array}$ & $\begin{array}{l}\text { Argillaceous but } \\
\text { applies to all types of } \\
\text { host rocks using EBS }\end{array}$ & $\begin{array}{l}\text { Specific to crystalline but } \\
\text { principles can be applied } \\
\text { to other rocks }\end{array}$ & $\begin{array}{l}\text { Depends on choice of host rock and } \\
\text { repository concept but all have general } \\
\text { safety assessment interest }\end{array}$ & $\begin{array}{l}\text { Applies to all types of } \\
\text { host rocks }\end{array}$ \\
\hline $\mathrm{BMT} / \mathrm{TC}$ & $\mathrm{TC}$ & $\mathrm{TC}$ & $\mathrm{TC}$ & $\mathrm{BMT} / \mathrm{TC}$ & $\mathrm{BMT} / \mathrm{TC}$ & BMT \\
\hline $\begin{array}{l}\text { Impact on } \\
\mathrm{PA} / \mathrm{SA}\end{array}$ & $\begin{array}{c}\text { Important for EBS } \\
\text { PA \& total system } \\
\text { SA }\end{array}$ & $\begin{array}{l}\text { Important for } \\
\mathrm{EDZ} \text { and } \\
\text { permeability field } \\
\text { and final SA } \\
\end{array}$ & $\begin{array}{l}\text { Important for EBS PA } \\
\text { \& total system SA }\end{array}$ & $\begin{array}{c}\text { Important for site } \\
\text { characterisation and total } \\
\text { system SA }\end{array}$ & $\begin{array}{l}\text { Important for EBS PA } \\
\text { and total system SA }\end{array}$ & $\begin{array}{l}\text { Important for scientific } \\
\text { basis of radioactive } \\
\text { waste disposal }\end{array}$ \\
\hline $\begin{array}{l}\text { Special } \\
\text { features }\end{array}$ & $\begin{array}{l}\text { Intimate interaction } \\
\text { with } \mathrm{D}-2015 \text { for } \\
\text { modelling and } \\
\text { testing }\end{array}$ & $\begin{array}{l}\text { Measured data } \\
\text { are available }\end{array}$ & $\begin{array}{l}\text { Intimate interaction } \\
\text { with PEBS project for } \\
\text { follow-up of the test }\end{array}$ & $\begin{array}{l}\text { Intimate interaction with } \\
\text { D-2015 for tracer test } \\
\text { design }\end{array}$ & Published data \& literature support & $\begin{array}{l}\text { Published data \& } \\
\text { literature support }\end{array}$ \\
\hline $\begin{array}{l}\text { Group } \\
\text { leader }\end{array}$ & IRSN (France) & Benoit & Benoit & $\begin{array}{c}\text { RAWRA } \\
\text { (Czech Republic) }\end{array}$ & $\begin{array}{l}\text { Co-ordinator to be allocated once the } \\
\text { specific past D-Task is chosen }\end{array}$ & $\begin{array}{l}\text { Lanru Jing \& } \\
\text { John A Hudson } \\
\text { (during initial } \\
\text { planning) } \\
\end{array}$ \\
\hline $\begin{array}{l}\text { Initial } \\
\text { interest } \\
\text { shown on } \\
\text { Helsinki } \\
\end{array}$ & $\begin{array}{lc}\text { CAS } & \text { IRSN } \\
\text { JAEA } & \text { NDA } \\
\text { NRC } & \text { WHU(?) } \\
\text { DOE } & \\
\end{array}$ & $\begin{array}{l}\text { CAS WHU(?) } \\
\text { IRSN }\end{array}$ & $\begin{array}{c}\text { IRSN } \\
\text { NDA } \\
\text { KAER } \\
\text { WHU(?) }\end{array}$ & $\begin{array}{l}\text { RAWRA } \\
\text { KAERI } \\
\text { WHU(?) }\end{array}$ & $\begin{array}{c}\text { NRC } \\
\text { NDA(?) } \\
\text { RAWRA(?) }\end{array}$ & $\begin{array}{c}\text { CAS } \\
\text { NDA } \\
\text { RAWRA (?) }\end{array}$ \\
\hline
\end{tabular}


Of the six modeling test cases, Cases 1 and 3 are mostly relevant to the EBS work package of UFDC; both target the behavior of clay-based backfill and sealing materials in interaction with clay host rock. Cases 2, 4, and 6, the MB Test, the Bedrichov Tunnel Experiment, and the Single Fracture THMC Study, are mostly relevant to the NBS work package of UFDC. Case 5, revisiting previous DECOVALEX tasks, could be relevant to both work packages; however, it is not clear at this point which of the previous tasks may be selected. Details on Cases 1, 2, 3, 4, and 6 are given below. Note that not all of the six proposed modeling test cases are expected to be selected for DECOVALEX-2015. Based on initial interest by existing DECOVALEX participants (see Table 3-1 above), the likely tasks to move forward are Cases 1, 3, 4, and 6.

One issue to resolve soon is the question of how to handle the cost of international commitments such as the DECOVALEX project. A possible solution is that the "membership fee" for DOE participation would come out of some centralized international fund, while the staff support for active $R \& D$ would be covered out of the relevant UFDC work packages (e.g., EBS, NBS). The expected "membership fee" for DECOVALEX-2015 is about $\$ 42,000$ annually, somewhat dependent on the final number of participating organizations as well as the currency exchange rate. In the case of the DECOVALEX project, DOE membership ensures that all associated national laboratories will be allowed to participate.

\subsection{SEALEX Experiment at the Tournemire URL, France (Focus: EBS)}

The SEALEX experiment aims at investigating the long-term HM behavior and hydraulic performance of swelling clay-based seals (Figure 3-1). A suite of experiments will be conducted in several $60 \mathrm{~cm}$ diameter mini-tunnels (5 m long) that are exposed to nominal conditions, different technological choices for seal mixtures and emplacement, and altered situations (e.g., forced resaturation or not; loss of mechanical confinement or not) (Figure 3-2). Forced resaturation can lead to heterogeneous saturation and porosity/permeability fields within the bentonite core, and hence the possibility of claycore erosion due to flow channeling. The experiments will test these hydraulic parameters and their spatial distribution via state-of-the-art measurement technology (e.g., wireless sensors installed within the core to limit preferential flow along cables). Hydraulic tests (pulse tests + constant load tests) will eventually be conducted to determine the overall hydraulic properties (permeability, leaks) of the seals, for different representative conditions. While not decided yet, IRSN, the French Institute for Radiological Protection and Nuclear Safety, considers adding one particular test to the experimental plan that would evaluate HMC behavior with concrete/steel and concrete/bentonite interaction.

The SEALEX experiments are conducted at the Tournemire URL in the south of France. This site is characterized by a subhorizontal indurated argillaceous claystone layer $250 \mathrm{~m}$ thick. A railway tunnel, constructed in 1881 through the argillaceous formation, is $2 \mathrm{~km}$ long, $6 \mathrm{~m}$ high, and $4.7 \mathrm{~m}$ wide, and was excavated using a pneumatic tool. In 1996 and 2003, additional research tunnels were excavated off the main railway tunnel. Thus, this facility allows study of near-field rock behavior in indurated clay with different time 
periods of exposure to the atmosphere, namely 130, 15 and 8 years, respectively (Rejeb and Cabrera, 2006) (Figure 3-3).
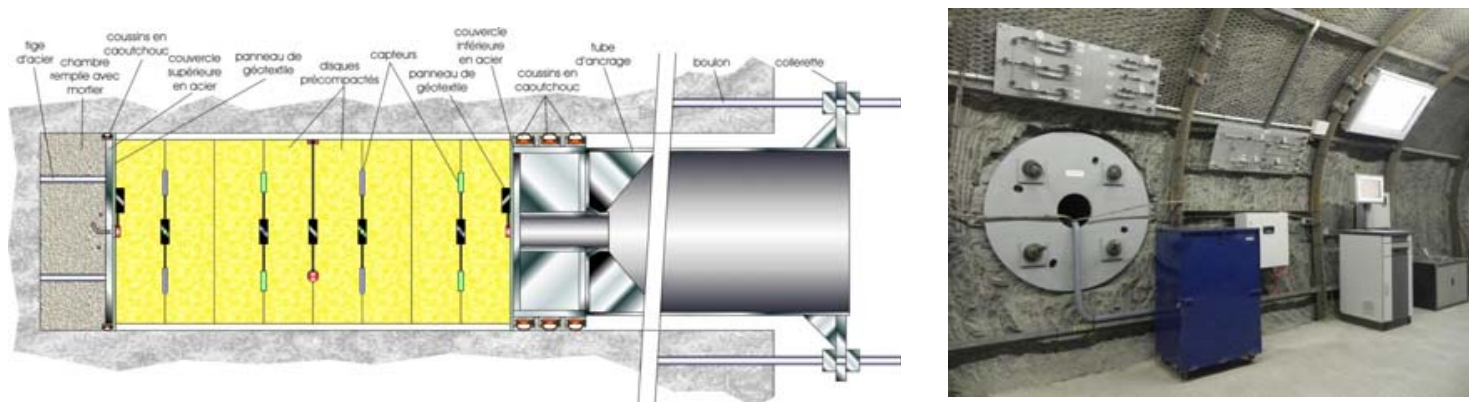

Figure 3-1. Schematic setup of mini-tunnel with seal core and instrumentation (left); view from gallery after core emplacement (right) (from Barnichon, 2011)

\begin{tabular}{|c|c|c|c|c|c|c|}
\hline & $\begin{array}{c}\text { Reference } \\
\text { Tests }\end{array}$ & $\begin{array}{l}\text { Performance } \\
\text { Tests }\end{array}$ & $\begin{array}{l}\text { Intra-core geometry } \\
\text { Core conditioning } \\
\text { Composition (MX80/sand) }\end{array}$ & Core view & $\begin{array}{c}\text { Altered } \\
\text { conditions }\end{array}$ & $\begin{array}{l}\text { Emplacement } \\
\text { date }\end{array}$ \\
\hline Base case & RT-1 & PT-N1 & $\begin{array}{l}\text { Monolithic disks } \\
\text { Precompacted } \\
(70 / 30)\end{array}$ & & No & $\begin{array}{l}12 / 2010 \\
06 / 2011\end{array}$ \\
\hline \multirow{4}{*}{$\begin{array}{l}\text { Variations } \\
\text { I Base case }\end{array}$} & - & PT-A1 & $\begin{array}{c}\text { Monolithic disks } \\
\text { Precompacted } \\
(70 / 30)\end{array}$ & & $\begin{array}{c}\text { Confinement } \\
\text { loss }\end{array}$ & $06 / 2012$ \\
\hline & - & PT-N2 & $\begin{array}{c}\text { Disks + internal joints }(4 / 4) \\
\text { Precompacted } \\
\text { (70/30) }\end{array}$ & & No & $12 / 2011$ \\
\hline & RT-2 & PT-N3 & $\begin{array}{l}\text { Pellets/powder } \\
\text { In situ compacted } \\
(100 / 0)\end{array}$ & & No & $\begin{array}{l}12 / 2012 \\
06 / 2013\end{array}$ \\
\hline & - & PT-N4 & $\begin{array}{c}\text { Monolithic disks } \\
\text { Precompacted } \\
(20 / 80)\end{array}$ & & No & $12 / 2013$ \\
\hline
\end{tabular}

Figure 3-2. Planned experiments and schedule (from Barnichon, 2011)

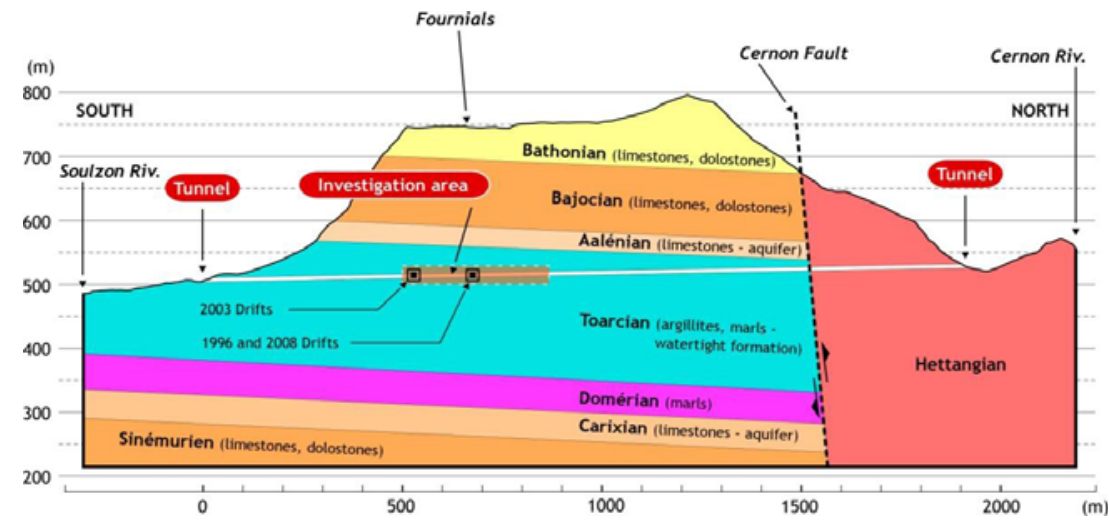

Figure 3-3. Geological cross section of the Tournemire site (from Barnichon, 2011) 


\subsection{MB Test at Mont Terri URL, Switzerland (Focus: NBS)}

The MB Mine-By Test at the Mont Terri URL, shown in Figure 3-4, involved tunneling through a pre-instrumented region of Opalinus Clay (see Section 4 for more information on the Mont Terri URL). The test, which was conducted at full tunnel scale, has been completed recently, and several years of data on excavation disturbed zone (EDZ) behavior are available for modeling and interpretation. The test allows evaluating the excavation-generated pressure, stress, displacement, and rock damage response in the argillaceous clay host rock near a mined tunnel, and also provides measurements of related changes in the near-field hydrologic properties. Data available for analysis include stress and convergence measurements, pore-pressure results, and hydrotest results before and after mining. Some of the most interesting observations are related to the fact that pore pressure and deformation signals can be observed several meters before the advancing tunnel face, a response that cannot be easily explained with existing constitutive relationships. New fractures created in the EDZ show interaction with bedding planes and crosscutting joints. Mine-by leads to a significant increase of hydraulic conductivity by up to four orders of magnitude. Note that the MB Test niche functions as the access gallery to the tunnel sections that hosts the soon-to-be-conducted FE Heater Test (see Section 4).

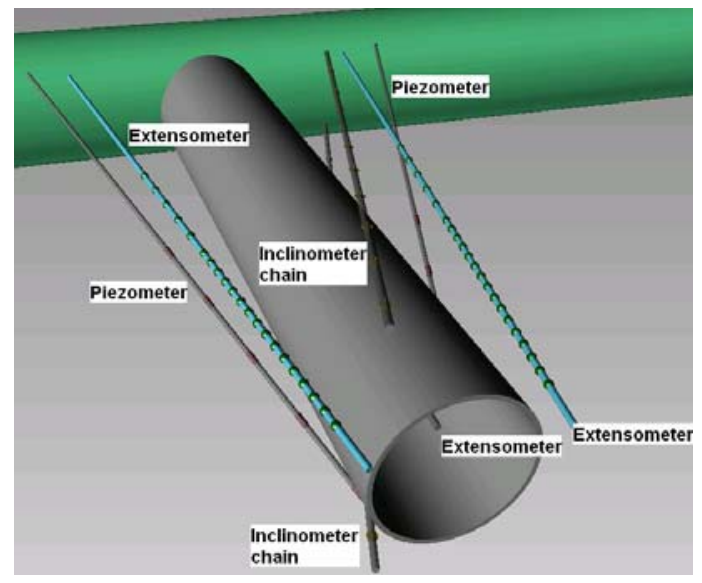

Figure 3-4. Schematic setup of MB Mine-by test at Mont Terri showing location of selected boreholes for piezometer, extensometer, and inclinometer data (from Vietor et al., 2011)

\subsection{HE-E Heater Test at Mont Terri URL, Switzerland (Focus: EBS and its interaction with NBS)}

The HE-E Heater Test at the Mont Terri URL, shown in Figure 3-5, focuses on the THM behavior of bentonite barriers in the early nonisothermal resaturation stage and the THM interaction with Opalinus Clay (see Section 4 for more information on the Mont Terri URL). The objective is to better understand the evolution of a disposal system of highlevel waste in the early postclosure period, with emphasis on the thermal evolution, buffer resaturation (in situ determination of the thermal conductivity of bentonite and its 
dependency on saturation), pore water pressure in the near field, and the evolution of swelling pressures in the buffer. Because the test is conducted in a micro-tunnel (at 1:2 scale), it is considered a validation, not a demonstration experiment. The heater test involves two types of bentonite buffer materials. The heater-buffer interface will be heated to a maximum of $135^{\circ} \mathrm{C}$, and a temperature of $60-70^{\circ} \mathrm{C}$ is expected at the bufferrock interface. A dense instrumentation network is already in place in the host rock surrounding the micro-tunnel (from a previous experiment testing the impact of ventilation on the clay host rock) and will be improved (up to 40 piezometers in total); various sensors will also be placed in the buffer material. Heating is expected to start in late summer of 2011 and will be continued for at least three years.
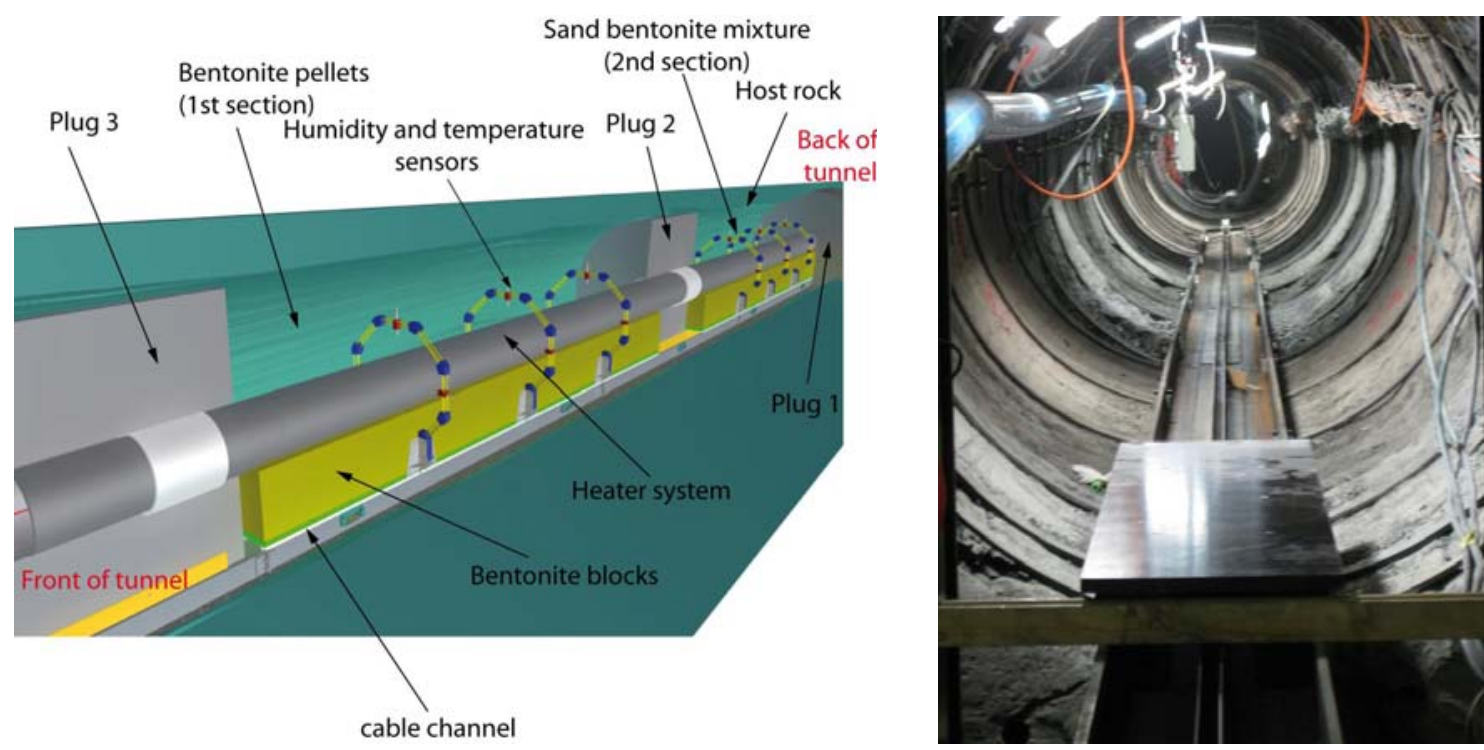

Figure 3-5. Schematic setup of HE-E heater test at Mont Terri and photo of micro-tunnel (from Garitte et al., 2011)

\subsection{Bedrichov Tunnel Experiment, Czech Republic (Focus: NBS)}

The Bedrichov tunnel is an existing tunnel of 2,600 m length located in the Northern Czech Republic. The tunnel hosts a water pipe, but was recently made available for geologic studies. NAWRA (the Radioactive Waste Management Authority of the Czech Republic) and associated university researchers use the tunnel as an underground laboratory to study the suitability of the Bohemian granitic massif as a host rock for a radioactive waste repository (Figure 3-6). The modeling test case proposed for DECOVALEX-2015 aims at better understanding and predicting flow patterns and tracer transport behavior within the fractured rock, between the ground surface (about $120 \mathrm{~m}$ above the tunnel axis) and the tunnel. Measured data include tunnel water inflow patterns and rates (vs. infiltration at ground surface), water temperature, and water chemistry, the latter including chemical composition of major elements, $\mathrm{pH}$, and several natural isotopes as tracers. Discrete fracture representations of the fractured granite surrounding the tunnel have been built based on fracture mapping in the tunnel and electrical resistivity profiles. 

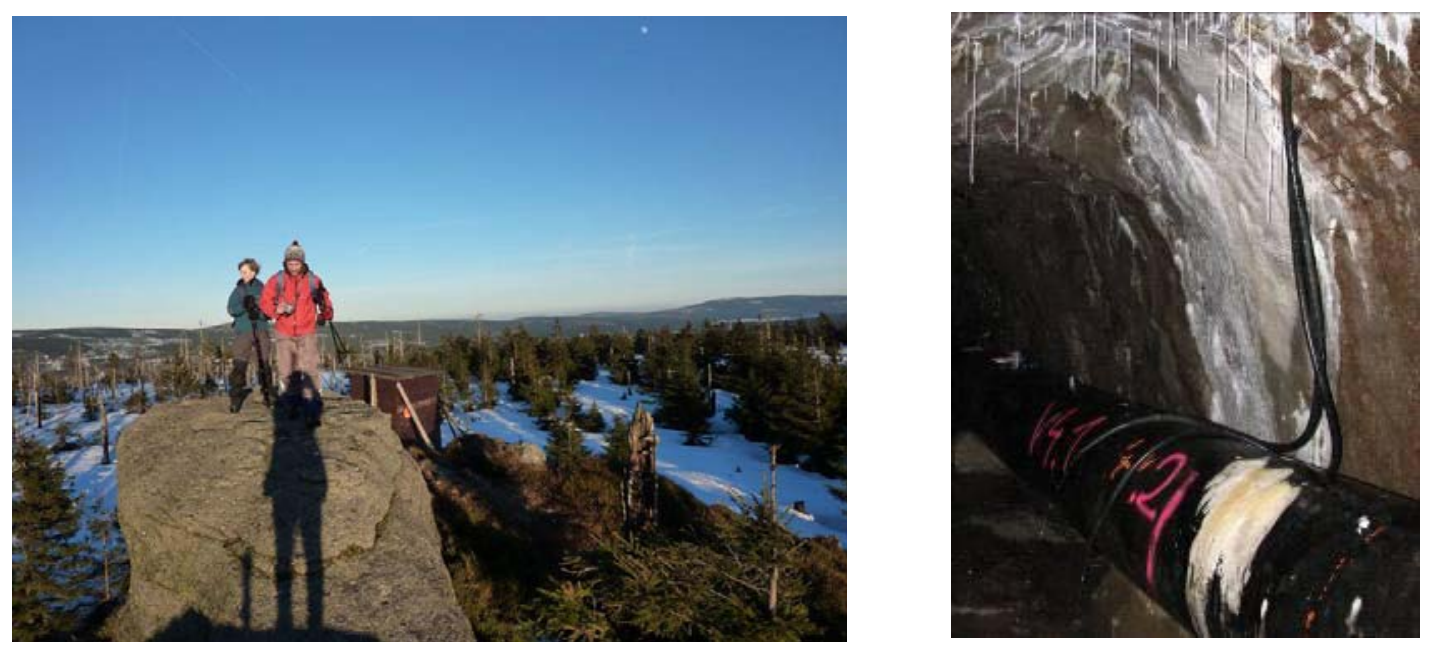

Figure 3-6. Bohemian granitic massif in Czech Republic and Water Inflow Evidence in the Bedrichov Tunnel (from Hokr and Slovak, 2011)

\subsection{THMC Processes in Single Fractures (Focus: NBS)}

This modeling task proposes to use data from single-fracture-flow laboratory experiments to evaluate the linkage of thermal stresses mediating chemical effects, and conversely of chemical potentials mediating mechanical behavior (e.g., pressure solution), and how any of these processes affects flow behavior. This task requires fully coupled THMC model capabilities, which only recently have become available and still require thorough validation. Early laboratory experiments available to target such THMC behavior have been conducted on single rock fractures in novaculite (a form of microcrystalline or cryptocrystalline quartz) (Figure 3-7) (Polak et al., 2003; Yasuhara et al., 2004). These experiments involved reactive flow-through compression and shear tests conducted on single natural-fracture specimens at different temperature, stress, and chemical conditions. The experiments were constrained by concurrent monitoring of stress/strain, influent and effluent flows/chemical reactants, and by intermittent nondestructive imaging by x-ray CT. More recently, similar experiments have been conducted on granite and tuff fractures (Rutqvist and Min, 2011). The data sets from these experiments can be used for the validation of THMC models with direct CM coupling between chemical reaction and strain. 


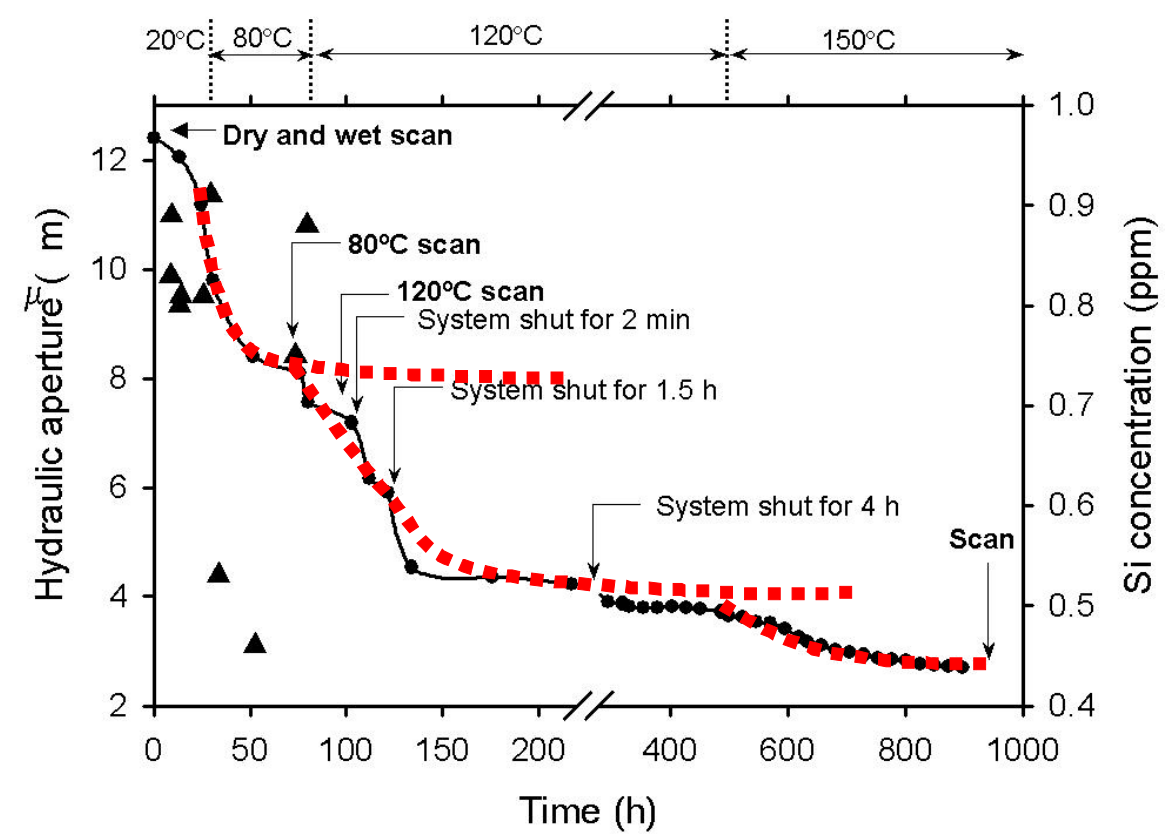

Figure 3-7. Results showing THMC behavior effects in a single fracture exposed to different external temperatures and varying stress conditions (from Polak et al., 2003)

\subsection{DECOVALEX Summary}

\section{Benefits of Participation:}

- Access to four to six sets of experimental data from different URLs and different host rock environments

- Focus is on modeling and analysis of existing data in collaboration with other modeling groups (typically less direct interaction with the project teams that run or interpret the experiments)

- No opportunity for influencing, proposing, or conducting own experiments (however, opportunity to suggest DOE modeling test cases)

\section{Conditions of Participation in DECOVALEX-2015:}

DOE needs to formally join the DECOVALEX project and pay an annual fee that covers the cost of administrative and technical matters. Participating organizations provide funding to their own research teams to work on some or all of the problems defined in the project. The next DECOVALEX phase, named DECOVALEX-2015, will start in early 2012, and will run for four years until 2015. A commitment by DOE over this four-year project phase is needed. The expected "membership fee" is about $\$ 42,000$ annually, somewhat dependent on the final number of participating organizations as well as the currency exchange rate. 
Proposed Test Cases, Main FEPs Addressed, and Relevance to Safety Case:

\begin{tabular}{|c|c|}
\hline \multicolumn{2}{|c|}{ HE-E Heater Test at Mont Terri URL, Switzerland (Focus: EBS and its interaction with NBS) } \\
\hline $\begin{array}{l}\text { THM validation experiment } \\
\text { in microtunnel }\end{array}$ & $\begin{array}{l}\text { EBS: Non-isothermal resaturation behavior in bentonite backfill } \\
\text { NBS: Interaction of near-field clay rock with EBS components }\end{array}$ \\
\hline $\begin{array}{l}\text { Engineered Systems FEPS } \\
\text { Buffer/Backfill materials in } \\
\text { clay, salt, crystalline rock }\end{array}$ & $\begin{array}{l}\text { 2.1.04.01: Buffer/Backfill } \rightarrow \text { High } \\
\text { 2.1.07.02, .03., .04., .09: Mechanical Processes } \rightarrow \text { Medium } \\
\text { 2.1.08.03, .07, .08: Hydrological Processes } \rightarrow \text { Medium } \\
\text { 2.1.11.04: Thermal Processes } \rightarrow \text { Medium }\end{array}$ \\
\hline $\begin{array}{l}\text { Geosphere FEPS²: } \\
\text { (for shale) }\end{array}$ & $\begin{array}{l}\text { 2.2.01: Excavation Disturbed Zone (EDZ) } \rightarrow \text { High }(\text { Shale })^{3} \\
\text { 2.2.07: Mechanical Processes } \rightarrow \text { Medium (Shale) } \\
\text { 2.2.08: Hydrologic Processes } \rightarrow \text { Medium (Shale) } \\
\text { 2.2.11: Thermal Processes } \rightarrow \text { Medium (Shale) }\end{array}$ \\
\hline \multicolumn{2}{|c|}{ SEALEX Experiment at the Tournemire URL, France (Focus EBS) } \\
\hline $\begin{array}{l}\mathrm{HM}(\mathrm{C}) \text { validation experiment } \\
\text { in microtunnel }\end{array}$ & $\begin{array}{l}\text { EBS: Long-term isothermal HM behavior and hydraulic performance of } \\
\text { swelling clay-based seals }\end{array}$ \\
\hline $\begin{array}{l}\text { Engineered Systems FEPS }{ }^{1}: \\
\text { Seal/liner materials }\end{array}$ & $\begin{array}{l}\text { 2.1.05.01: Buffer/Backfill } \rightarrow \text { Medium } \\
\text { 2.1.07.02, .08., .09: Mechanical Processes } \rightarrow \text { Medium } \\
\text { 2.1.08.04, .05, .07, .08, .09: Hydrological Processes, Flow Through Seals } \\
\rightarrow \text { Medium } \\
\text { 2.1.09.01, .03, .09, .13: Chemical Processes - Chemistry } \rightarrow \text { Medium }\end{array}$ \\
\hline \multicolumn{2}{|c|}{ MB Test at Mont Terri URL, Switzerland (Focus: NBS) } \\
\hline $\begin{array}{l}\text { HM full-scale validation } \\
\text { experiment }\end{array}$ & $\begin{array}{l}\text { NBS: Excavation-generated response in the argillaceous clay host rock } \\
\text { near a mined tunnel, including changes in the near-field hydrologic } \\
\text { properties }\end{array}$ \\
\hline $\begin{array}{l}\text { Geosphere FEPS²: } \\
\text { (for shale) }\end{array}$ & $\begin{array}{l}\text { 2.2.01: Excavation Disturbed Zone }(E D Z) \rightarrow \text { High (Shale) } \\
\text { 2.2.07: Mechanical Processes } \rightarrow \text { Medium (Shale) } \\
\text { 2.2.08: Hydrologic Processes } \rightarrow \text { Medium (Shale) }\end{array}$ \\
\hline \multicolumn{2}{|c|}{ Bedrichov Tunnel Experiment, Czech Rebublic (Focus: NBS) } \\
\hline $\begin{array}{l}\text { Natural flow and transport } \\
\text { experiment }\end{array}$ & $\begin{array}{l}\text { NBS: Flow patterns and tracer transport behavior within fractured } \\
\text { crystalline rock }\end{array}$ \\
\hline $\begin{array}{l}\text { Geosphere FEPS }{ }^{2}: \\
\text { (for crystalline rock) }\end{array}$ & $\begin{array}{l}\text { 2.2.02: Host Rock Properties } \rightarrow \text { High (Crystalline) } \\
\text { 2.2.05: Flow and Transport Pathways } \rightarrow \text { Medium (crystalline) } \\
\text { 2.2.08: Hydrologic Processes } \rightarrow \text { Medium (Crystalline) }\end{array}$ \\
\hline \multicolumn{2}{|c|}{ THMC Processes in Single Fractures (Focus: NBS) } \\
\hline $\begin{array}{l}\text { Small-scale THMC } \\
\text { laboratory experiments }\end{array}$ & $\begin{array}{l}\text { NBS: Fully coupled THMC behavior in different rock types (crystalline, } \\
\text { tuff) }\end{array}$ \\
\hline Geosphere FEPS ${ }^{2}:$ & $\begin{array}{l}\text { 2.2.07: Mechanical Processes } \rightarrow \text { Low (Crystalline) } \\
\text { 2.2.08: Hydrologic Processes } \rightarrow \text { Low (Crystalline) } \\
\text { 2.2.09: Chemical Processes - Transport } \rightarrow \text { Medium (Crystalline) } \\
\text { 2.2.011: Chemical Processes - Transport } \rightarrow \text { Low (Crystalline) }\end{array}$ \\
\hline earch and Developmen & $\begin{array}{l}\text { ion Campaign Disposal Research and Development Roadmap (Nutt, 2011) } \\
\text { ion Campaign Disposal Research and Development Roadmap (Nutt, 2011) } \\
\text { Clay/Shale is highest-scoring FEP in Used Fuel Disposition Campaign Disposal } \\
\text { (Nutt, 2011; Appendix B) }\end{array}$ \\
\hline
\end{tabular}




\section{MONT TERRI PROJECT}

The Mont Terri Project is an international research project for the hydrogeological, geochemical and geotechnical characterization of a clay/shale formation suitable for geologic disposal of radioactive waste (Zuidema, 2007; Bossart and Thury, 2007). The project, which was officially initiated in 1996, utilizes an underground rock laboratory, which lies north of the town of St-Ursanne in Northwestern Switzerland and is located at a depth of $\sim 300 \mathrm{~m}$ below the surface in argillaceous claystone (Opalinus Clay). The rock laboratory is located in and beside the security gallery (initially the reconnaissance gallery) of the Mont Terri motorway tunnel which was opened to traffic at the end of 1998. The rock laboratory consists mainly of eight small niches along the security gallery, excavated in 1996, the gallery 98 and 5 lateral niches, excavated in 1997/98, a gallery for the EZ-A experiment, excavated in 2003, the gallery 04 and 4 lateral niches, excavated in 2004, and lastly, the gallery 08 and side galleries for the FE Heater Test and MB test, excavated in 2008 (Figure 4-1).

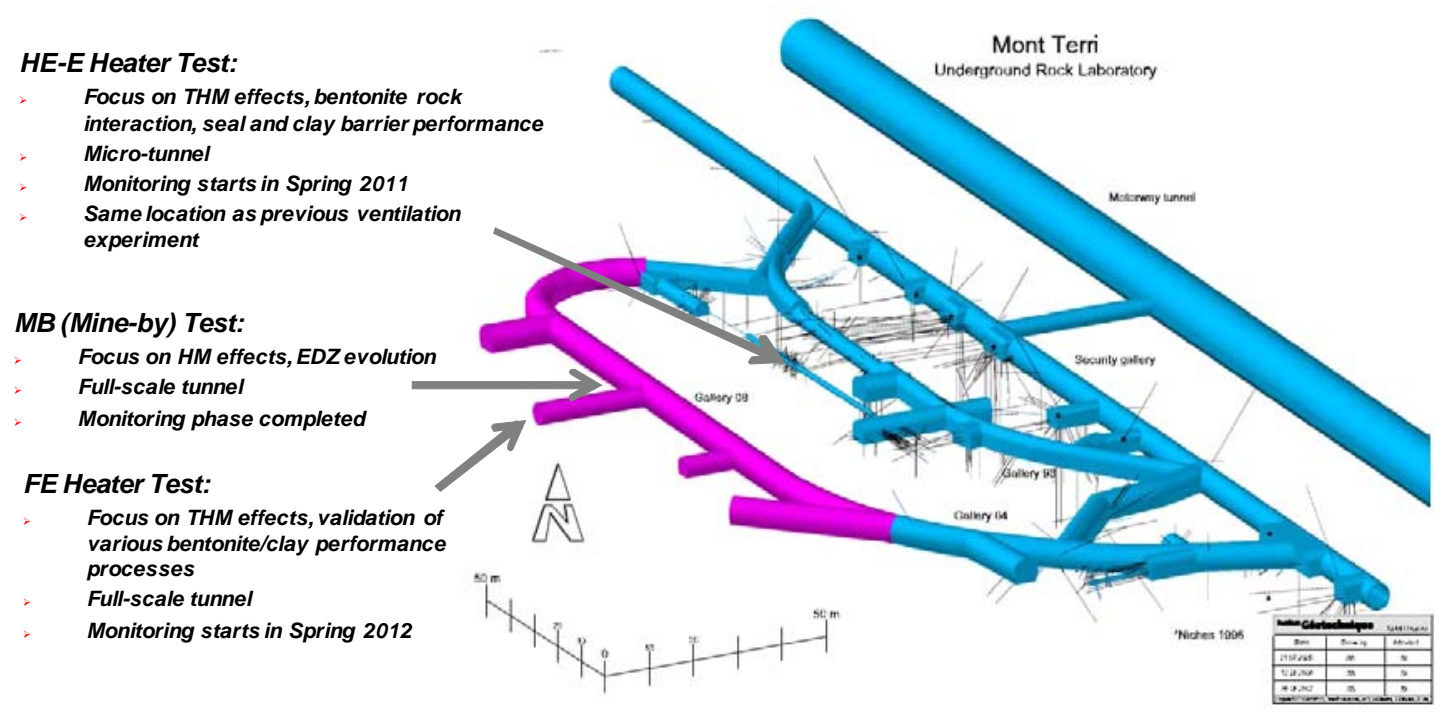

Figure 4-1. Summary schematic of the Mont Terri URL with side galleries and drifts for testing. Three specific experiments of relevance to UFDC are highlighted (based on Garitte, 2010).

The Mont Terri Project essentially operates as a collaborative program providing open access to an existing URL. The research program consists of a series of individual experiments and is divided into annual project phases. Mont Terri partner organizations may select and conduct experiments, may participate in experiments conducted by others, and they have access to all project results from past and ongoing efforts. Planning, steering and financing is the responsibility of the partners participating in the experiment. (Larger field experiments are therefore often conducted by more than one organization.) Current project partners are from Switzerland (swisstopo/SGS, ENSI, NAGRA), Belgium (SCK/CEN), France (ANDRA, IRSN), Germany (BGR, GRS), Japan (OBAYASHI, JAEA, CRIEPI), Spain (ENRESA, Empresa), Canada (NWMO), and USA (Chevron). 
These organizations have provided substantial financial investments, and additional sponsorship has been contributed by the European Community, and by the Swiss Federal Office for Science and Education. It is not surprising, therefore, that the project has been very successful and a wide range of experimental studies on clay/shale behavior (including backfill/buffer behavior) have been conducted over the years (e.g., Table 4-1, Figure 4-2).

Participation of DOE as a partner in the Mont Terri Project would provide UFDC researchers access to relevant field data and project results from past efforts. More importantly, UFDC researchers can work collaboratively with international scientists on ongoing and future experimental studies, which would include all design, characterization, modeling, and interpretation aspects related to field experiments. In the long term, UFDC researchers would also be able to propose and eventually conduct their own experiments at the Mont Terri URL. This type of international collaboration goes beyond the mostly modeling focus of DECOVALEX, and may arguably be the most fruitful approach to active international R\&D. Three prominent experiments are currently being conducted or are in preparation stages, two of which are also proposed as DECOVALEX modeling test cases (e.g., the HE-E Heater Test with focus mostly on EBS and the MB Mine-By Test with focus on NBS, as introduced in Section 3 above). The third one, referred to as the FE Heater Test (described below in more detail), is a long-term ( $>10$ years), full-scale test that will serve as an ultimate validation and demonstration test for emplacement of heat-producing waste in Opalinus Clay, at realistic temporal and spatial scales. Validation will include THM coupling effects with focus on both the NBS host rock behavior and the EBS components.

Table 4-1. List of experiments being conducted at Mont Terri, from 1996 through 2005 (from Bossart and Thury, 2007)

\begin{tabular}{|c|c|c|c|c|c|c|c|c|c|}
\hline EXPERIMENTS: phases & $\begin{array}{ll}1996 & 1997 \\
1+2 & \end{array}$ & $\begin{array}{l}1998 \\
3\end{array}$ & $\begin{array}{l}1999 \\
4\end{array}$ & $\begin{array}{l}2000 \\
5\end{array}$ & $\begin{array}{l}2001 \\
6\end{array}$ & $\begin{array}{l}2002 \\
7\end{array}$ & $\begin{array}{l}2003 \\
8\end{array}$ & $\begin{array}{l}2004 \\
9\end{array}$ & $\begin{array}{l}2005 \\
10\end{array}$ \\
\hline Water circulation $(4 \mathrm{ex})$ & AENJS & AENJS & AENJS & AENJS & AEJS & AESF & $\mathrm{F}$ & $\mathrm{F}$ & $\mathrm{F}$ \\
\hline In situ water sampling + analysis & AENJS & AEINJS & $\mathrm{AN}$ & $\mathrm{AN}$ & & & & & \\
\hline Porewater extraction + anal. (7 ex) & ANJS & AEINJS & AEIN & & & ABENS & ABENS & ABECNS & ABECNS \\
\hline Water and gas permeability ( $3 \mathrm{ex})$ & ANS & ANS & ANS & ANS & & $\mathrm{BN}$ & & & \\
\hline Porewater pressures & A & A & & & & & & & \\
\hline Rock stresses (4 ex) & $\mathrm{AN}$ & A & $\mathrm{A}$ & B & B & B & B & B & $\mathrm{BA}$ \\
\hline Structure of EDZ (6 ex) & ABENO & ABENO & ABENO & $A B E N$ & BEN & B & & $\mathrm{ABNH}$ & $\mathrm{ABNH}$ \\
\hline Self-sealing of EDZ ( 2 ex) & & ANS & ANS & ANS & NS & $\mathrm{N}$ & $\mathrm{N}$ & $\mathrm{N}$ & $\mathrm{N}$ \\
\hline Osmosis & ANS & AINS & AINS & AINS & & INS & INS & & \\
\hline Cement Waters & AENO & AENO & ANO & ANO & NO & NO & & & $\mathrm{N}$ \\
\hline Diffusion of radionuclides (4 ex) & & AEIJNS & AEIJNS & AEIJNS & AEIJNS & EIJN & AEIN & AEN & AGEIN \\
\hline Heater experiments $(3 \mathrm{ex})$ & & $\mathrm{AE}$ & $\mathrm{AE}$ & AEG & AEGN & ABEGN & & ABEGN & $\mathrm{AGN}$ \\
\hline Geochemical synthesis & & & AEIN & ABEIJN & ABEIJN & ABEIN & & & \\
\hline Rock mech. and hydrogeol. synth. & & & & ABINO & BINO & ABINO & BINO & BHINO & BINO \\
\hline Engineerd barrier, Sealing & & & & & BEN & BEN & BEN & BEN & BGENO \\
\hline Ventilation & & & & & & EGIN & EGIN & EGIN & BEGIN \\
\hline
\end{tabular}

In order for DOE to become a formal Mont Terri partner, there are two main requirements: (1) the present Mont Terri Project partners have to unanimously accept new partner organizations, and (2) as a buy-in, new partners have to invest about 500K 
Swiss Francs (about $\$ 600 \mathrm{~K}$ at current exchange rate, status June 2011), which can be spread over a period of 3 years. The buy-in fee can partially be provided in kind (i.e., by having UFDC researchers conduct work). The fraction of in-kind contributions can be negotiated with the Mont Terri partners, but is expected to be somewhere between 30 to $50 \%$ of the total. In addition to the "membership fee" for DOE participation, staff support for active R\&D would be covered out of the relevant UFDC work packages (e.g., NBS, EBS). After the first three years, partners need to invest a minimum of $50 \mathrm{~K}$ Swiss Francs per year into the research program.

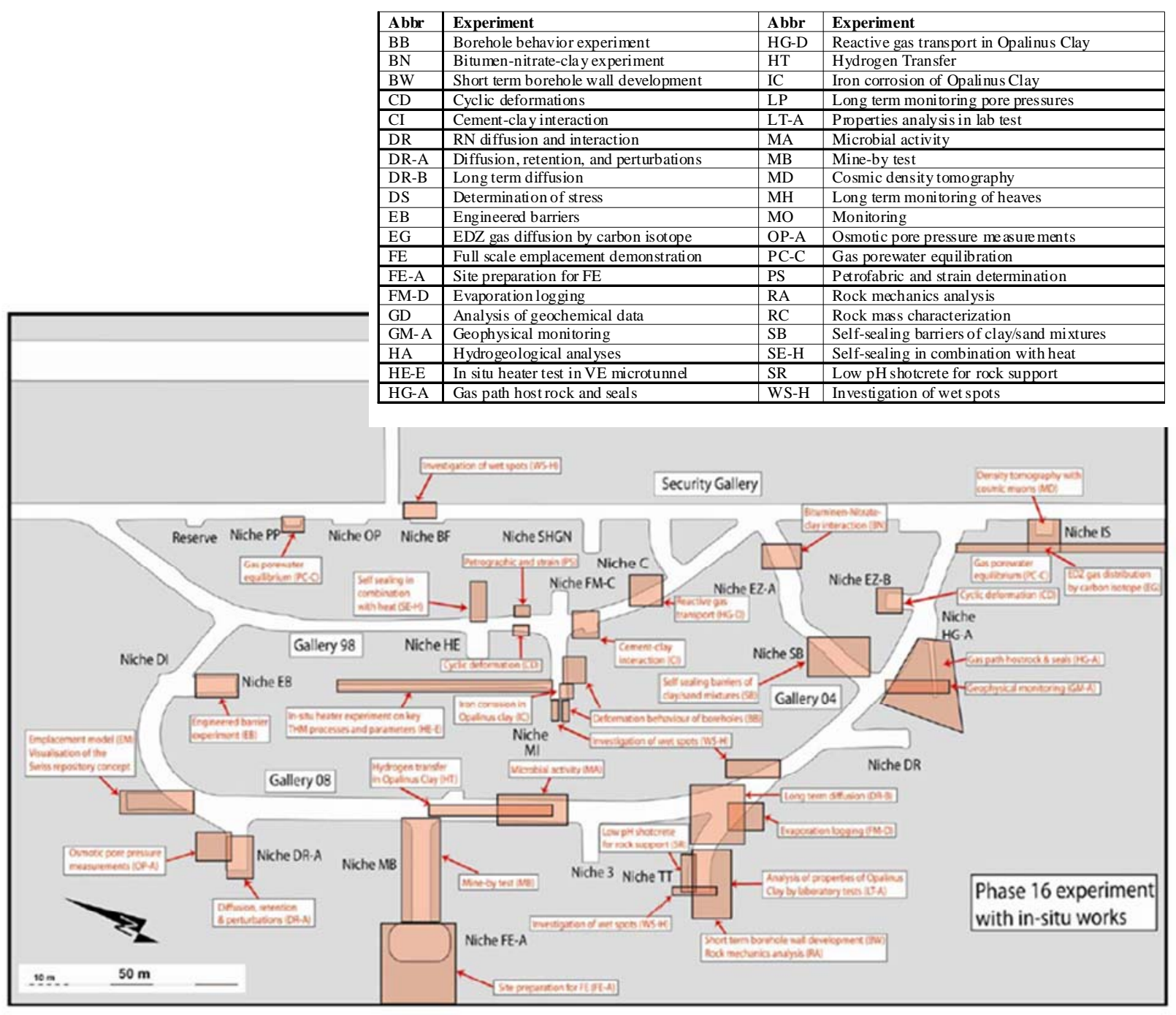

Figure 4-2. Plan view of Mont Terri with locations of Phase 16 experiments, status September 2010 (from Vietor, 2011). 


\subsection{FE Heater Test (Focus: both NBS and EBS)}

Because of its potential relevance to UFDC's NBS and EBS areas, we provide here some further detail on the FE Heater Test, one of the largest and longest-duration heater tests worldwide (Figures 4.3 and 4.4). As mentioned before, this heater experiment is undertaken by NAGRA and other European partners as an ultimate test for the performance of geologic disposal in Opalinus Clay, with focus on both the EBS components and the host-rock behavior. The experiment will provide data useful for the validation of THM coupling effects regarding the processes in the host rock while correctly accounting for (and examining) the conditions in the emplacement tunnel (temperature, saturation, and swelling pressure). Due to the 1:1 scale of the experiment, it will be possible to achieve realistic temperature, saturation, and stress gradients. It will also be possible to test backfilling technology with granular bentonite as well as lining technology with shotcrete, anchors, and steel rips. Processes examined in the test cover many aspects of repository evolution, such as EDZ creation and desaturation of the EDZ during tunnel excavation and operation (including ventilation for about one year), as well as reconsolidation of the EDZ, resaturation, thermal stresses, and thermal pore pressure increase after backfilling and heating (heating and monitoring period $>10$ years).

As shown in Figures 4-2 and 4.3, the FE Heater Test will be conducted in a side tunnel at Mont Terri, excavated along the claystone bedding plane for this purpose, with $50 \mathrm{~m}$ length and about $2.8 \mathrm{~m}$ diameter. Heating from emplaced waste will be simulated by three heat-producing canisters of $1500 \mathrm{~W}$ maximum power. A sophisticated monitoring program is planned, including dense pre-instrumentation of the site for in situ characterization, dense instrumentation of bentonite buffer and host rock, and extensive geophysical monitoring (seismic and electric “tomography”). A THM modeling program will be conducted in parallel with the testing and monitoring activities.

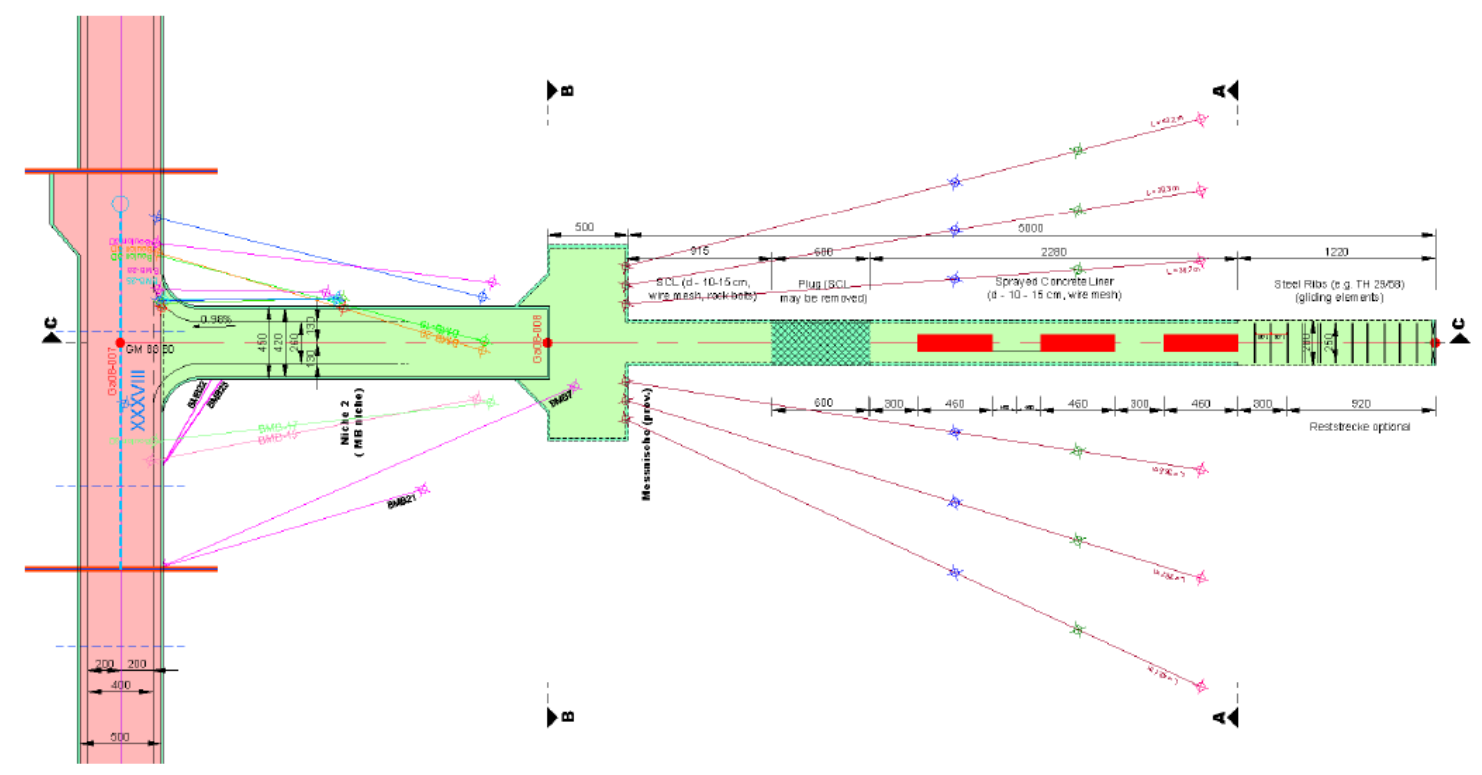

Figure 4-3. Plan view of experiment setup and borehole layout (from Garitte, 2010) 


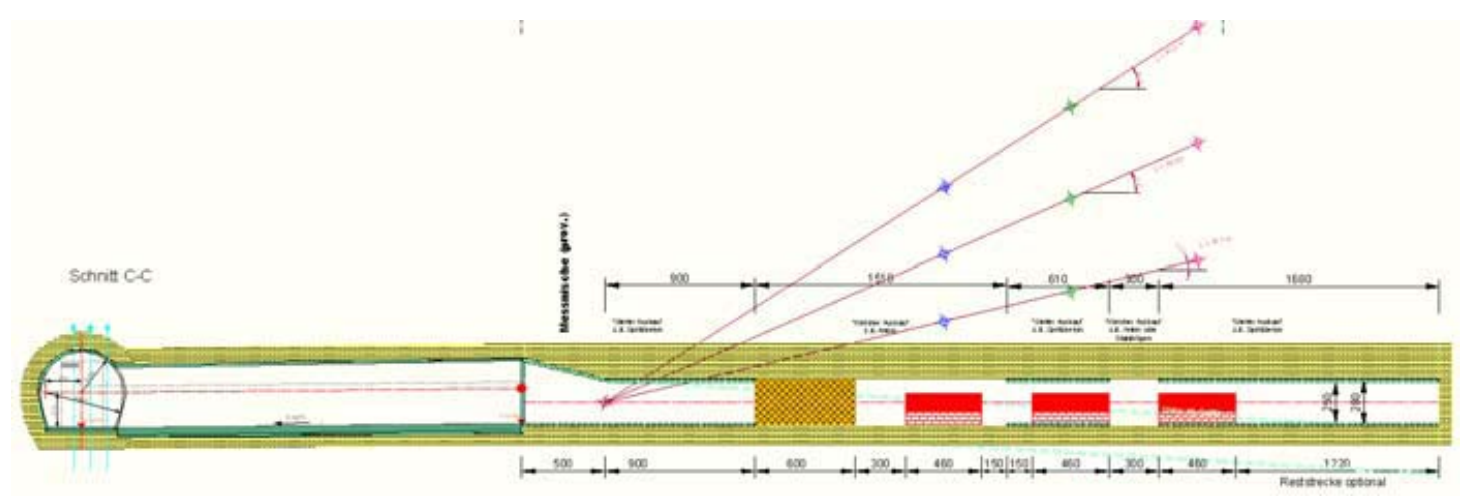

Figure 4-4. Side view of experiment setup and borehole layout (from Garitte, 2010)

\subsection{Mont Terri Summary}

\section{Benefits of Participation:}

- Access to experimental data from one URL in clay/shale host rock, with many past, ongoing and future experiments addressing various FEPs

- Opportunity to participate directly in international research groups that conduct, analyze, and model experiments (more direct involvement than DECOVALEX): Most relevant to UFDC are three recent, ongoing or soon-to-be-started major experiments (FE Heater Test, HE-E Heater Test, MB Test)

- Opportunity for participating in and steering ongoing or planned experiments as well as conducting own experiments

\section{Conditions of Participation:}

DOE needs to formally join the Mont Terri Project. In order to join, the present Mont Terri Project partners have to unanimously accept DOE, and an initial buy-in of 500K Swiss Francs (about $\$ 600 \mathrm{~K}$ at current exchange rate, status June 2011) is needed, which can be spread over a period of 3 years and partially provided in kind. After three years, a minimum investment of $50 \mathrm{~K}$ Swiss Francs per year is required. Mont Terri partner organizations may select and conduct their own experiments, may participate in other experiments, and they have access to all project results from past and ongoing efforts. Planning, steering and financing an experiment is the responsibility of the partners participating in the experiment. 
Main Experiments, FEPs Addressed, and Relevance to Safety Case:

\begin{tabular}{|c|c|}
\hline \multicolumn{2}{|c|}{ FE Heater Test (Focus: both NBS and EBS) } \\
\hline $\begin{array}{l}\text { Full-scale long-term THM } \\
\text { demonstration experiment }\end{array}$ & $\begin{array}{l}\text { NBS: Many aspects of near-field shale repository evolution, such as EDZ } \\
\text { creation, desaturation and resaturation, thermal effects, pore pressure } \\
\text { increase after backfilling and heating } \\
\text { EBS: Performance of EBS backfilling and lining technology }\end{array}$ \\
\hline $\begin{array}{l}\text { Geosphere FEPS }{ }^{1} \text { : } \\
\text { (for shale) }\end{array}$ & $\begin{array}{l}\text { 2.2.01: Excavation Disturbed Zone }(E D Z) \rightarrow \text { High }\left(\text { Shale) }{ }^{2}\right. \\
\text { 2.2.07: Mechanical Processes } \rightarrow \text { Medium (Shale) } \\
\text { 2.2.08: Hydrologic Processes } \rightarrow \text { Medium (Shale) } \\
\text { 2.2.11: Thermal Processes } \rightarrow \text { Medium (Shale) }\end{array}$ \\
\hline $\begin{array}{l}\text { Engineered Systems FEPS } \\
\text { Buffer/Backfill materials in } \\
\text { clay, salt, crystalline rock }\end{array}$ & $\begin{array}{l}\text { 2.1.04.01: Buffer/Backfill } \rightarrow \text { High } \\
\text { 2.1.07.02, .03., .04., .09: Mechanical Processes } \rightarrow \text { Medium } \\
\text { 2.1.08.03, .07, .08: Hydrological Processes } \rightarrow \text { Medium } \\
\text { 2.1.11.04: Thermal Processes } \rightarrow \text { Medium }\end{array}$ \\
\hline $\begin{array}{l}\text { Engineered Systems FEPS } \\
\text { Seal/liner materials }\end{array}$ & $\begin{array}{l}\text { 2.1.05.01: Buffer/Backfill } \rightarrow \text { Medium } \\
\text { 2.1.07.02, .08., .09: Mechanical Processes } \rightarrow \text { Medium } \\
\text { 2.1.08.04, .05, .07, .08, .09: Hydrological Processes } \rightarrow \text { Low }\end{array}$ \\
\hline \multicolumn{2}{|c|}{ HE-E Heater Test (Focus: EBS and its interaction with NBS) } \\
\hline $\begin{array}{l}\text { THM validation experiment } \\
\text { in microtunnel }\end{array}$ & $\begin{array}{l}\text { EBS: Non-isothermal resaturation behavior in bentonite backfill } \\
\text { NBS: Interaction of near-field shale rock with EBS components }\end{array}$ \\
\hline $\begin{array}{l}\text { Engineered Systems FEPS } \\
\text { Buffer/Backfill materials in } \\
\text { clay, salt, crystalline rock }\end{array}$ & $\begin{array}{l}\text { 2.1.04.01: Buffer/Backfill } \rightarrow \text { High } \\
\text { 2.1.07.02, .03., .04., .09: Mechanical Processes } \rightarrow \text { Medium } \\
\text { 2.1.08.03, .07, .08: Hydrological Processes } \rightarrow \text { Medium } \\
\text { 2.1.11.04: Thermal Processes } \rightarrow \text { Medium }\end{array}$ \\
\hline $\begin{array}{l}\text { Geosphere FEPS }{ }^{1} \text { : } \\
\text { (for shale) }\end{array}$ & $\begin{array}{l}\text { 2.2.01: Excavation Disturbed Zone (EDZ) } \rightarrow \text { High }(\text { Shale })^{2} \\
\text { 2.2.07: Mechanical Processes } \rightarrow \text { Medium (Shale) } \\
\text { 2.2.08: Hydrologic Processes } \rightarrow \text { Medium (Shale) } \\
\text { 2.2.11: Thermal Processes } \rightarrow \text { Medium (Shale) }\end{array}$ \\
\hline \multicolumn{2}{|l|}{ MB Test (Focus: NBS) } \\
\hline $\begin{array}{l}\text { HM full-scale validation } \\
\text { experiment }\end{array}$ & $\begin{array}{l}\text { NBS: Excavation-generated response in the argillaceous clay host rock } \\
\text { near a mined tunnel, including changes in the near-field hydrologic } \\
\text { properties }\end{array}$ \\
\hline $\begin{array}{l}\text { Geosphere FEPS }{ }^{1} \text { : } \\
\text { (for shale) }\end{array}$ & $\begin{array}{l}\text { 2.2.01: Excavation Disturbed Zone }(E D Z) \rightarrow \text { High }(\text { Shale) } \\
\text { 2.2.07: Mechanical Processes } \rightarrow \text { Medium (Shale) } \\
\text { 2.2.08: Hydrologic Processes } \rightarrow \text { Medium (Shale) }\end{array}$ \\
\hline es: & $\begin{array}{l}\text { ion Campaign Disposal Research and Development Roadmap (Nutt, 2011) } \\
\text { Clay/Shale is highest-scoring FEP in Used Fuel Disposition Campaign Disposal } \\
\text { (Nutt, 2011; Appendix B) }\end{array}$ \\
\hline
\end{tabular}




\section{COLLOID FORMATION AND MIGRATION PROJECT}

The Colloid Formation and Migration (CFM) Project is an international research project for the investigation of colloid formation/bentonite erosion, colloid migration, and colloid-associated radionuclide transport, relevant to both NBS and EBS areas of UFDC. This collaborative project is one of several experimental R\&D projects associated with the Grimsel Test Site (GTS) in the Swiss Alps, a URL situated in sparsely fractured crystalline host rock (http://www.grimsel.com/). Colloid-related R\&D comprises in situ migration experiments conducted between boreholes in a fracture shear zone; these are complemented by laboratory and modeling studies. Current CFM project partners are from Germany (KIT and GRS), Japan (JAEA, CRIEPI), Sweden (SKB), Spain (CIEMAT), South Korea (KAERI), Finland (POSIVA), and Switzerland (NAGRA).

The main R\&D objectives, relevant to both NBS and EBS issues, are as follows:

- To examine colloid generation rates and mechanisms at the Engineered Barrier System (EBS)-host rock boundary under in situ conditions,

- To study the long-term geochemical behavior (mobility, mineralization, colloid formation, etc.) of radionuclides at the EBS-host rock boundary,

- To evaluate the long-distance migration behavior of radionuclides and colloids in water-conducting features in a repository-relevant flow system (i.e., with a very low flow rate/water flux),

- To examine reversibility of radionuclide uptake onto colloids,

- To gain experience in long-term monitoring of radionuclide/colloid propagation near a repository.

The CFM project was preceded by the Colloid and Radionuclide Retardation (CRR) project, conducted at the Grimsel Test Site from 1997 to 2003. Twenty-seven field tracer tests were conducted during the CRR, including seven that involved short-lived radionuclides, one involving a suite of radionuclides that included isotopes of $\mathrm{U}, \mathrm{Np}, \mathrm{Am}$, and $\mathrm{Pu}$, and one involving a suite of radionuclides (including $\mathrm{Cs}, \mathrm{Sr}, \mathrm{Tc}, \mathrm{U}, \mathrm{Np}, \mathrm{Am}$, and $\mathrm{Pu}$ isotopes) injected with bentonite colloids. Colloid-facilitated radionuclide transport was quantified by comparing the breakthrough curves of the radionuclides in the latter two tests (with and without the colloids). Similar tests with and without colloids were also conducted using nonradioactive homologues of actinides (e.g., stable isotopes of Th, $\mathrm{Hf}$, and $\mathrm{Tb}$ ). All of the CRR tests were conducted as weak-dipole tests between boreholes completed in a fracture shear zone (the MI shear zone), with the tests involving radionuclides being conducted between boreholes separated by $2.2 \mathrm{~m}$. Tracer residence times in all tests were no more than a few hours.

The CFM project was initiated soon after the Grimsel Test Site transitioned to Phase VI testing in 2004. While similar in many respects to the CRR project, the CFM project aimed to improve or expand upon CRR in two key areas: (1) increase tracer residence times in the shear zone to allow interrogation of processes that may not be observed over the very short time scales of the CRR tests (e.g., colloid filtration, radionuclide desorption from colloids), and (2) directly evaluate the performance of bentonite backfill 
with respect to swelling, erosion, and colloid generation by emplacing a bentonite plug into a borehole completed in the fracture shear zone. To accomplish these objectives, a "tunnel packer" system was installed to seal off the entire access tunnel where it was intersected by the shear zone (Figure 5-1). With this packer system, the flow rate from the shear zone into the tunnel could be throttled back from a natural rate of $\sim 700 \mathrm{ml} / \mathrm{min}$ to any desired value, and the water from the shear zone could be collected in a controlled manner. Boreholes penetrating the shear zone could then be used as injection boreholes for tracer tests or for emplacement of the bentonite plug, with the tunnel packer effectively serving as an extraction location.

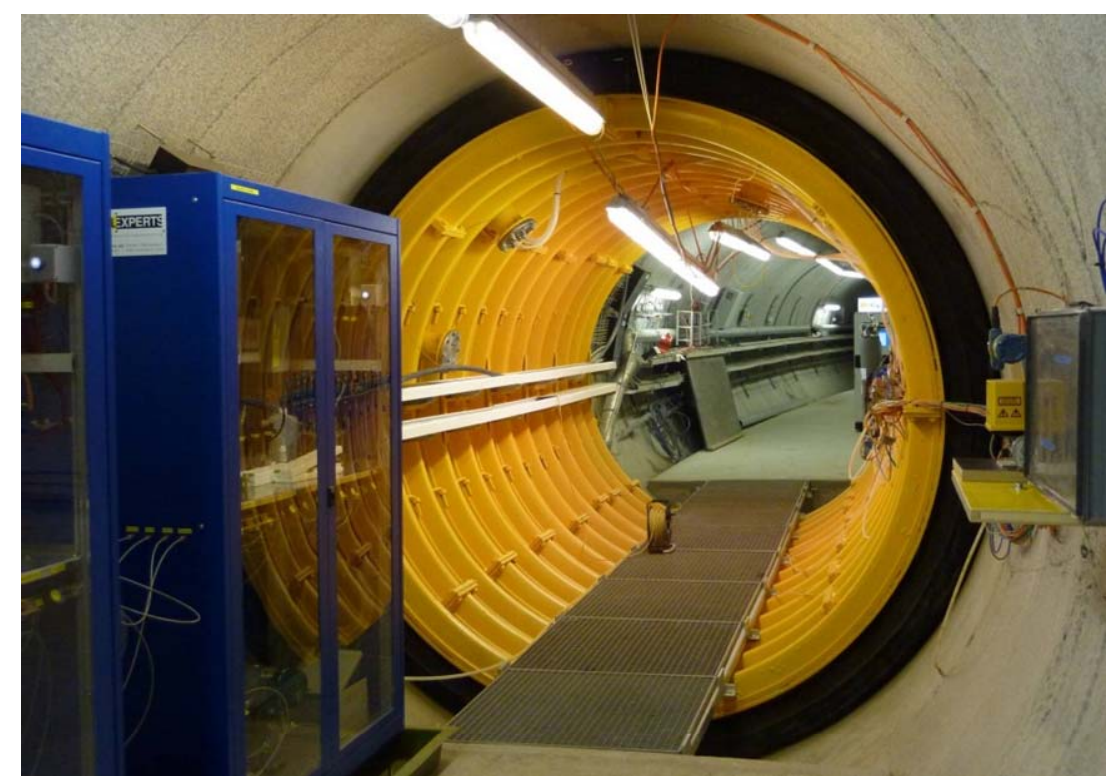

Figure 5-1. Tunnel packer system used to isolate the MI shear zone. Small disks with tubing issuing from them (inside yellow packer) are "surface packers" that seal the tunnel wall and collect water from inflow points. Tunnel diameter is 3.5 meters.

Seven conservative (nonsorbing) tracer tests were conducted in late 2006 through 2007 at various shear zone flow rates using different boreholes as injection holes to test the tunnel packer system and to evaluate tracer residence times that could be achieved. Tracer flow pathways in these tests and in all the CRR tests are depicted in Figure 5.2, which shows the locations of several boreholes relative to the main tunnel within the MI shear zone. Borehole CFM 06.002, drilled in 2006 for the CFM project, was established as the primary injection borehole to be used in subsequent tracer testing involving colloids, homologues and radionuclides. In 2008, a tracer test was conducted in which a bentonite colloid solution with homologues pre-sorbed onto the colloids was injected into CFM 06.002. This test was followed immediately with a conservative tracer test in the same configuration. Based on lessons learned from these tests, a series of five more tests were conducted in 2009 and 2010. Three of these included only conservative tracers, and two included bentonite colloids and homologues in addition to conservative tracers. Two new migration experiments are planned for the fall of 2011 and early 2012, respectively, 
which constitute the culmination of the CFM project during Phase VI testing at Grimsel. These are further described in Sections 5.1 and 5.2 below.

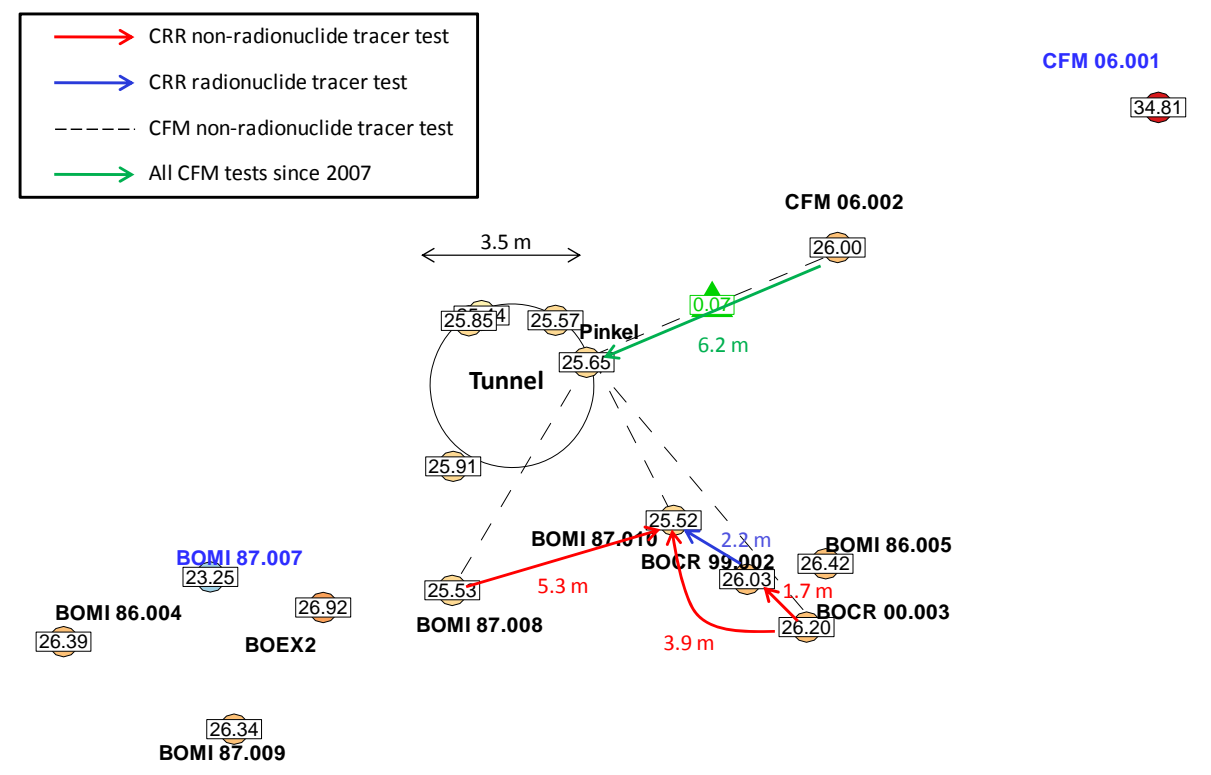

Figure 5-2. Tracer flow pathways and flow distances in the MI shear zone in all CRR and CFM tracer tests (2001-present). All boreholes penetrating the shear zone in the vicinity of the tunnel packer system are shown, with numbers inside boxes indicating head measurements (in meters) during a recent (2010) tracer test from CFM 06.002 to the "Pinkel" surface packer.

In addition to the field testing activities being conducted at the Grimsel Test Site, the CFM project includes many complementary activities aimed at helping achieve the R\&D objectives listed at the beginning of this section. These activities include:

- Bentonite swelling and erosion experiments in various laboratory configurations, including artificial fractures, to better understand the processes of swelling and erosion that will occur in the bentonite plug field experiment

- Laboratory sorption and desorption experiments of radionuclides and homologues onto both bentonite colloids and Grimsel fracture fill material

- Ternary sorption/desorption experiments involving the competitive sorption and desorption of radionuclides/homologues in the presence of both colloids and fracture fill material

- Colloid-facilitated radionuclide transport experiments in both crushed rock columns and in fractures in the laboratory.

- Laboratory efforts to improve detection and quantification methods for colloid analyses in field experiments, including possibly labeling the bentonite with a rare element that does not affect the behavior of the bentonite

- Development of a bentonite swelling/erosion model

- Interpretive modeling of the laboratory experiments and the field tracer tests 
Similar to the Mont Terri Project discussed above, DOE has the opportunity of becoming a formal partner of the Colloid Formation and Migration Project. Formal partnership would give DOE and affiliated national laboratories easier access to all experimental data generated by CFM. It would also encourage DOE interpretations of these experiments, which have only been qualitatively interpreted to date. More importantly, it would allow for UFDC researchers to work collaboratively with international scientists in ongoing experimental and modeling studies, and it would involve them in the planning of new experimental studies to be conducted in the future. Similar to the Mont Terri Project, this type of international collaboration goes beyond the mostly modeling focus of DECOVALEX. In contrast to both the DECOVALEX project and the Mont Terri project, which comprise a range of experiments covering a wide spectrum of relevant $R \& D$ issues, the CFM has a relatively narrow focus, i.e., colloid-facilitated radionuclide migration.

DOE partnership in CFM would require a "membership contribution” of approximately $85 \mathrm{~K}$ Swiss Francs per year, or $\sim \$ 102 \mathrm{~K}$ per year based on recent currency exchange rates (status June 2011). It is likely that a commitment of at least three years is required, but this has yet to be confirmed. In addition to the "membership fee" for DOE participation, staff support for active R\&D would be covered out of the relevant UFDC work packages (e.g., NBS, EBS).

\subsection{Colloid-Facilitated Radionuclide Tracer Test (Focus: NBS)}

A new colloid-facilitated radionuclide tracer test will be conducted in a fracture shear zone at Grimsel in late summer or fall of 2011. This test will involve the injection of a tracer/radionuclide "cocktail" that includes conservative tracers, weakly sorbing solutes, strongly sorbing solutes and bentonite colloids (generated from a bentonite obtained from a Spanish mine that is being considered for use in the Spanish nuclear waste disposal program). The radionuclides will be presorbed onto the colloids to varying degrees, dictated by their sorption to the colloids (probably 100\% sorbed for Pu and Am, 50\% sorbed for $\mathrm{U}$ and $\mathrm{Np}$, somewhere in between for fission products $\mathrm{Cs}$ and $\mathrm{Sr}$ ). As in all the recent CFM tracer tests, the test configuration will be a passive dipole with water being withdrawn from the tunnel wall at a fixed rate (probably $25 \mathrm{ml} / \mathrm{min}$ ) while the cocktail is continuously circulated through the injection interval (from the tunnel) with no net injection or withdrawal, with provisions to monitor the tracers in the circulation loop as the test progresses. The cocktail will bleed into the fracture shear zone, and concentrations in the circulation loop will decrease at a rate dictated by the flow rate through the injection interval induced by the withdrawal of water from the tunnel wall (i.e., very similar to a borehole point-dilution test).

Two previous colloid-facilitated transport tests were conducted in this configuration, but they involved nonradioactive homologues, not radionuclides. Prior to the above test, there will be at least one tracer test involving nonradioactive tracers to evaluate the ability to sample the fracture zone very close to the main injection borehole using three new smalldiameter boreholes drilled within a few $\mathrm{cm}$ of the injection borehole. The test(s) will also evaluate the influence that these new boreholes have on the flow field through the injection interval and to the tunnel wall. 


\subsection{Radionuclide-Doped Bentonite Plug Transport Experiment (Focus: both NBS and EBS)}

Late in 2011 or in early 2012, a bentonite plug (FEBEX backfill material) will be doped with a suite of radionuclides and emplaced into the CFM 06.002 injection interval used in previous tracer tests. The test configuration is schematically depicted in Figure 5-3. The exact method for doping the bentonite is still being worked out, but it will probably involve generating doped "pills" that are inserted into small holes drilled into the main bentonite plug at the depth of the fracture zone. Emplacement of the bentonite plug will be followed by long-term monitoring (over several years) of both colloids and radionuclides. Many of the same radionuclides will be used as in the test described above, but different isotopes will allow the observations from the two tests to be distinguished. The bentonite will be allowed to swell into the fracture zone and erode under the influence of the flow field, while samples are collected at the tunnel wall. The new small boreholes will be instrumented for sampling at very low rates to provide an early indication of swelling and radionuclide release. At the conclusion of the test, these boreholes will be filled with a resin to stabilize the rock mass, and a large-diameter overcore of the entire injection interval. While the primary purpose of this overcoring procedure is to recover the majority of the radionuclide inventory remaining at the source location at the conclusion of the test, this procedure will also afford the opportunity to do detailed postmortem characterizations of bentonite swelling into the fracture shear zone and determination of radionuclide dispositions in the emplacement borehole and shear zone at the end of the test.

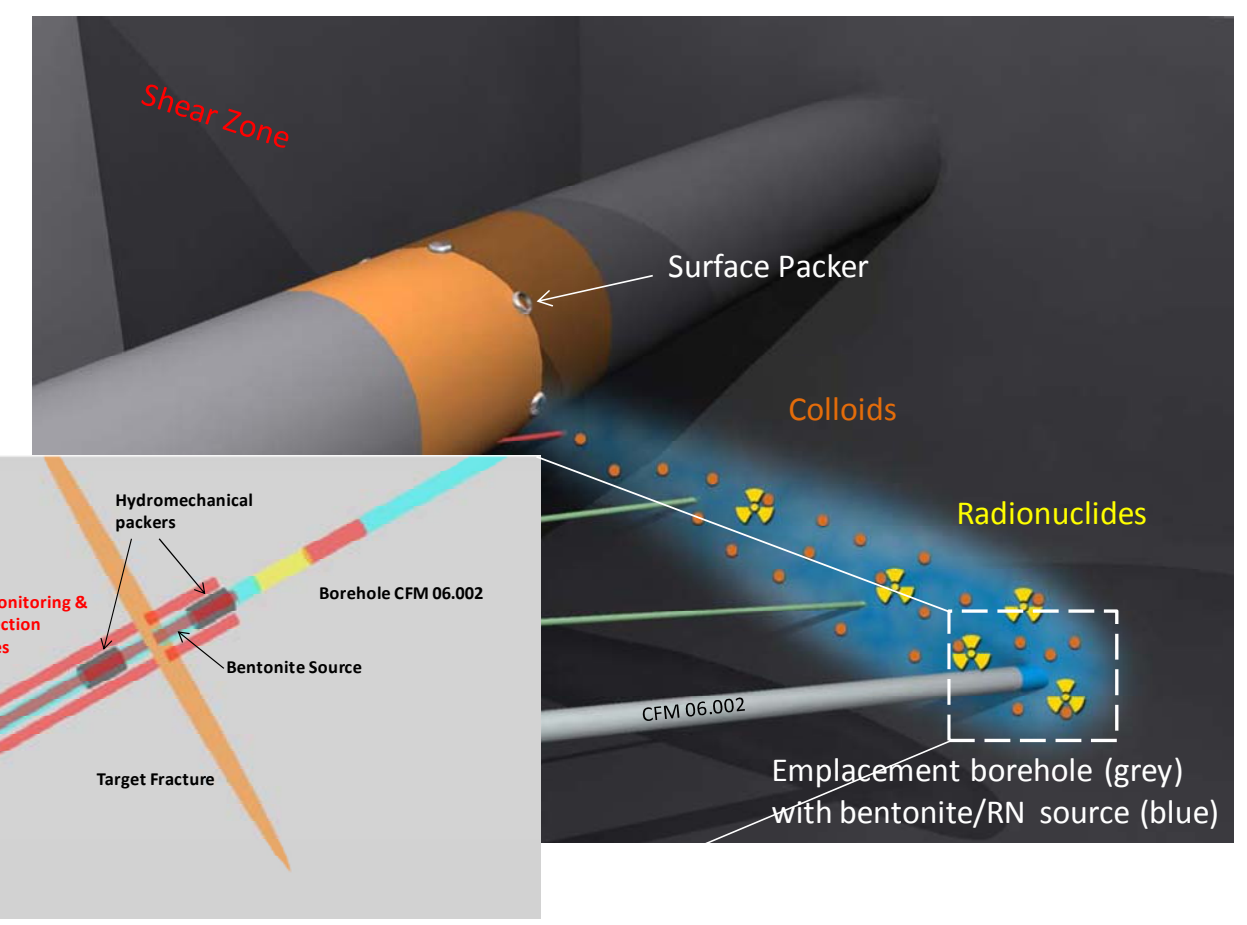

Figure 5-3. Schematic setup drawing of bentonite plug emplacement and bentonite swelling/erosion and colloid transport experiment. Note that the boreholes between CFM 06.002 and the main tunnel (green and red) will likely not be drilled. 


\subsection{Colloid Formation and Migration Summary}

\section{Benefits of Participation:}

- Access to experimental data from a suite of past, ongoing and future experiments on colloid-facilitated migration at Grimsel, more narrow focus than other initiatives (Note that CFM membership does not provide access to other experiments at Grimsel, such as FEBEX, etc.)

- Opportunity to participate directly in international research groups that conduct, analyze, and model migration experiments (more direct involvement than DECOVALEX): Most relevant to UFDC are two soon-to-be-started major experiments (Colloid-Facilitated RN Tracer Test, Radionuclide-Doped Bentonite Plug Transport Experiment)

- Opportunity for participating in and steering ongoing or planned experiments as well as conducting own experiments

\section{Conditions of Participation:}

DOE needs to formally join the Colloid Formation and Migration Project. DOE partnership would require a "membership contribution" of approximately 85K Swiss Francs per year, or $\sim \$ 102 \mathrm{~K}$ per year based on recent currency exchange rates (status June 2011). It is likely that a commitment of at least three years is required, but this has yet to be confirmed. CFM partner organizations have access to all project results from past and ongoing efforts, may participate in ongoing experiments, and/or may plan/conduct future experimental studies.

Main Experiments, FEPs Addressed, and Relevance to Safety Case:

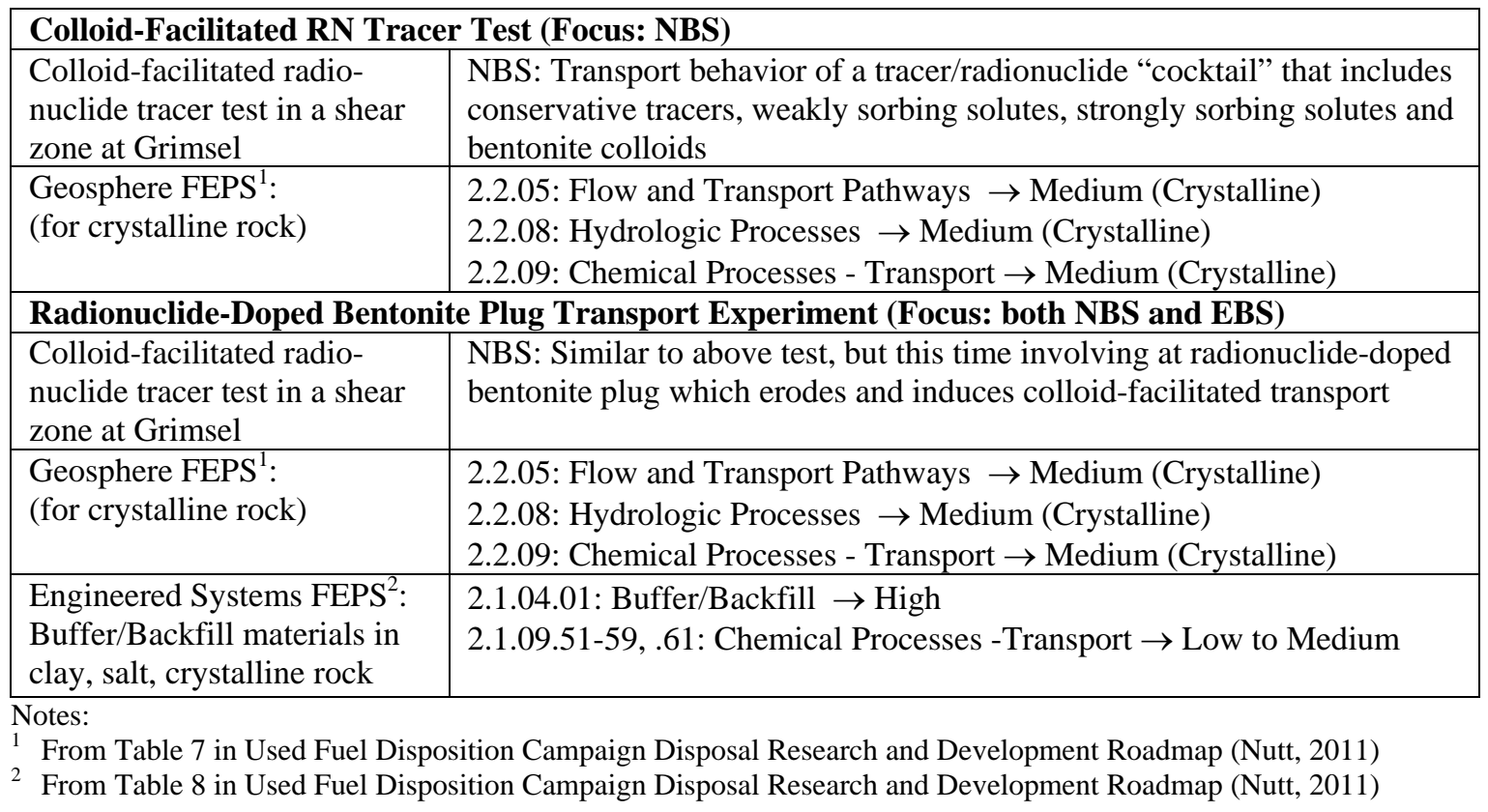




\section{OTHER ACTIVE COLLABORATION OPPORTUNITIES}

Access to data on international field experiments and participation of UFDC researchers in collaborative field studies may also be facilitated via direct informal or semi-formal agreements between national laboratories and international partners. Several UFDC scientists have close relationships with their international counterparts, resulting from workshops and symposia meetings, or from collaboration outside of UFDC's scope. International disposal programs are aware of the technical capabilities of UFDC scientists and are generally quite open to include them in their ongoing research teams. This may or may not require bilateral MoUs or other types of agreements. Below is a short list of selected major (soon-to-start or planned) field experiments conducted by international disposal programs that may be open to national laboratory participation, without "membership fees" or other long-term commitments on behalf of DOE. This list will need to be amended as new opportunities arise.

\subsection{Experiments at HADES URL in Mol, Belgium}

The HADES (High Activity Disposal Experimental Site) URL is located on a secured area belonging to one of Belgium's nuclear power plants, which also hosts other nuclear research facilities. HADES is essentially a several hundred meter long tunnel in the soft Boom Clay rock formation, accessible by two shafts located at each end Figure 6-1. The tunnels were drilled in stages, starting with a first section in 1982, followed by additions in 1987 and 2001. Each of these sections was secured with different types of ground support, reflecting the increasing knowledge about the structural behavior of the host rock. Most interesting to DOE's program is probably the upcoming PRACLAY heater experiment, and to a lesser degree ongoing clay diffusion experiments, both of which are discussed in more detail below. The Belgium organizations involved in conducting and interpreting these experiments (EIG Euridice, SCK CEN, ONDRAF/NIRAS) have longstanding relationships with scientists at Lawrence Berkeley National Laboratory (LBNL); they are open to participation of DOE research groups and have already invited LBNL researchers to provide THM modeling expertise to the PRACLAY project team.

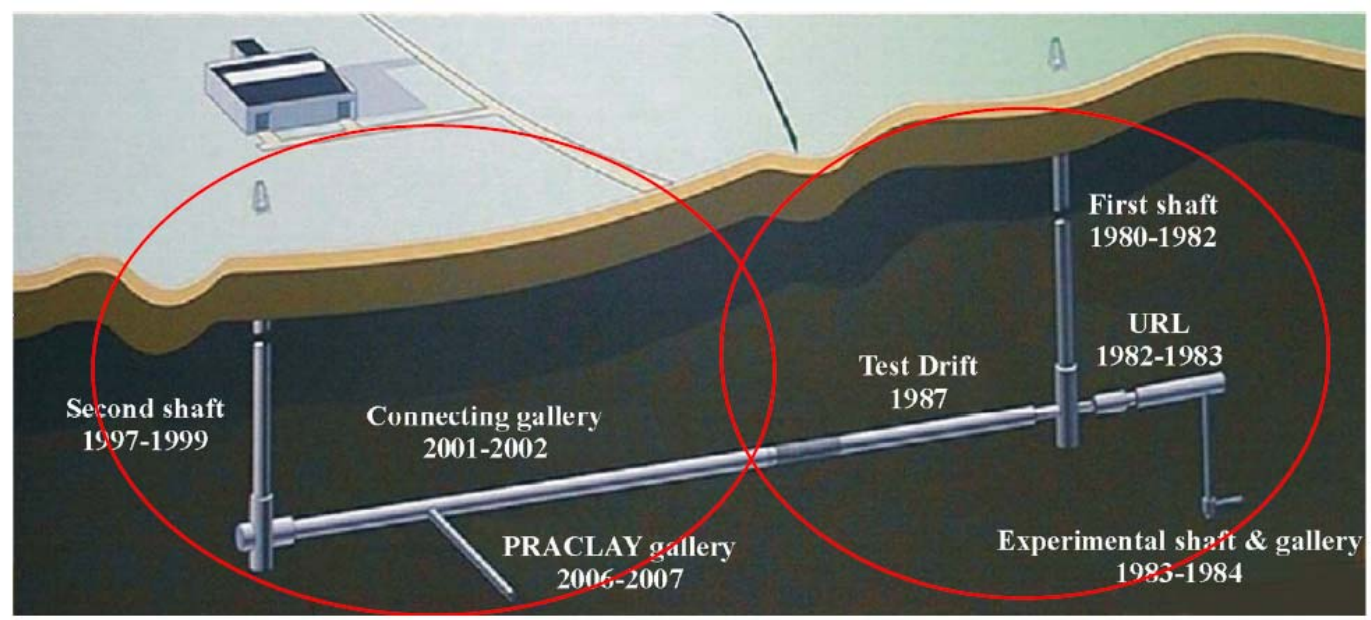

Figure 6-1. Layout of the HADES URL in Mol, Belgium 


\section{PRACLAY Test (Focus: mostly NBS, some EBS)}

The PRACLAY Heater Test is a full-scale validation and confirmation experiment to be conducted at the HADES URL, excavated at 223 m depth in Boom Clay, a tertiary clay formation in Mol, Belgium. The heater test, which will begin in early 2012, will involve heating a $30 \mathrm{~m}$ gallery section for 10 years with many monitoring sensors (Figures 6-2, 63 , and 6-4), for the purpose of investigating the thermo-hydro-mechanical (THM) behavior of near-field plastic clay under the most "mechanically critical" conditions that may occur around a repository (Van Marcke and Bastiaens, 2010). For plastic clay under the influence of temperature change, these are undrained conditions, which then generate a higher pore pressure increase and a higher possibility of near-field damage. For this objective, a hydraulic seal has been installed at the intersection between the planned heated and unheated sections of the gallery. This installation makes up the Seal Test, which was initiated in 2010, and allows testing the functionality of the hydraulic seal under heated repository conditions.

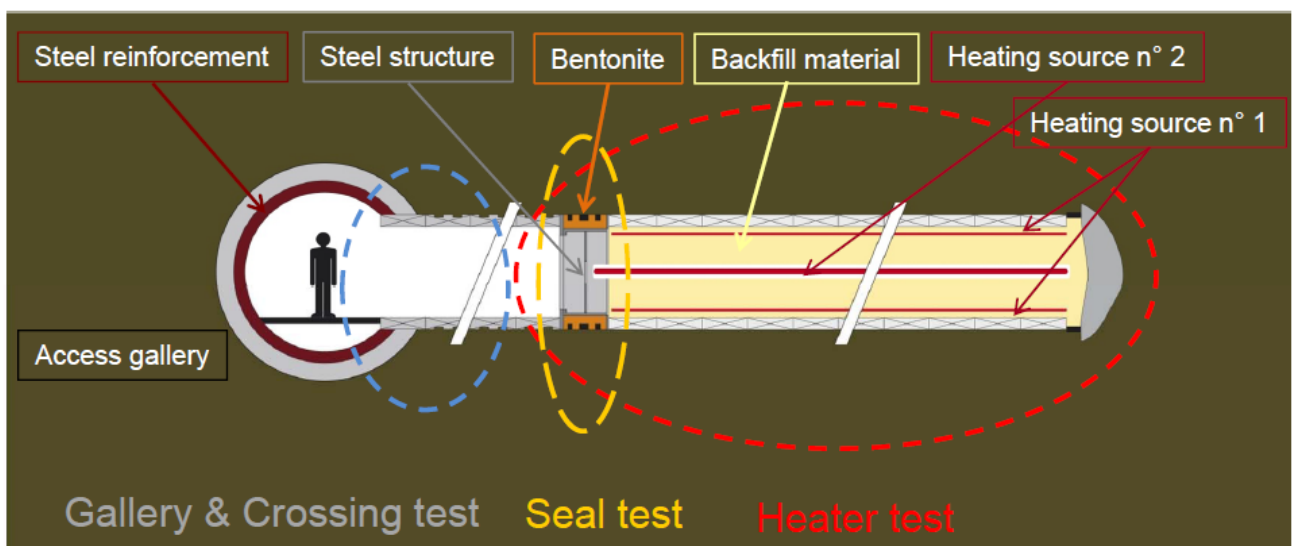

Figure 6-2. Layout of the PRACLAY In-Situ Experiment (from Li, 2011)

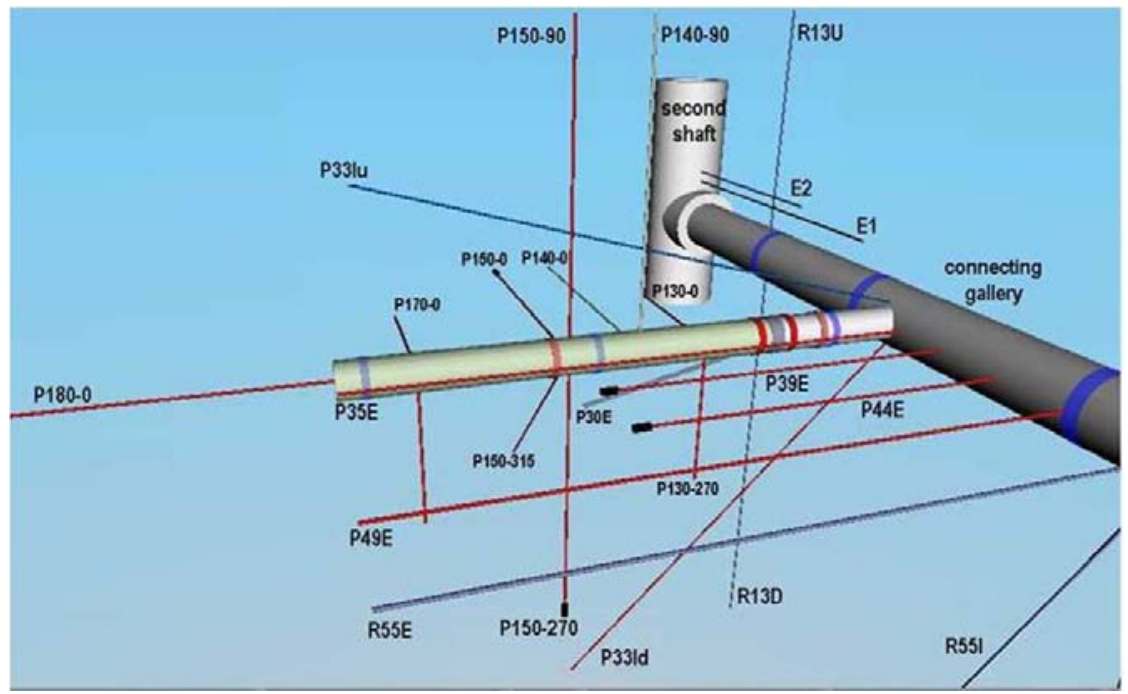

Figure 6-3. Configuration of boreholes for pressure, stress, displacement, and water chemistry measurements (from Li, 2011) 

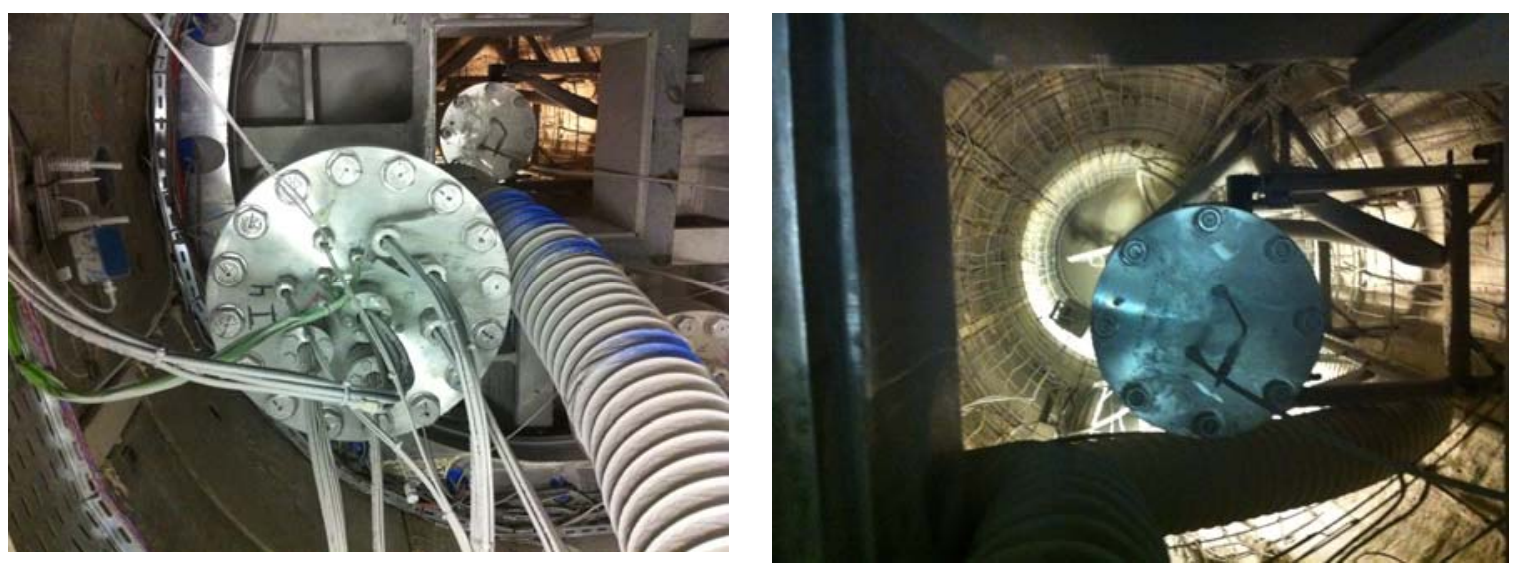

Figure 6-4. Photo on left shows hydraulic seal from the outside, with an access hole to the right which soon will be closed. Photo on right was taken from access hole into the heater gallery section, which is currently being backfilled (from Birkholzer, 2011)

\section{Radionuclide Migration Experiments (Focus: NBS)}

The Belgium waste management program has been conducting a suite of long-term radionuclide migration in situ experiments in dense clays at their HADES URL near Mol. Two of these experiments, named CP1 (Figure 6-5) and Tribicarb-3D, have been ongoing for 23 and 16 years, respectively, and offer valuable data on the slow diffusion-controlled migration of radionuclides in clay rocks. Because of their duration, they offer unique test cases for model and process validation. Recently, two other ongoing large-scale migration experiments were initiated at HADES. The TRANCOM test involves colloid transport with C-14 labeled humic substances. The RESEAL shaft seal experiment investigates transport of iodine-125 through the disturbed zone and the interface between Boom Clay and bentonite.

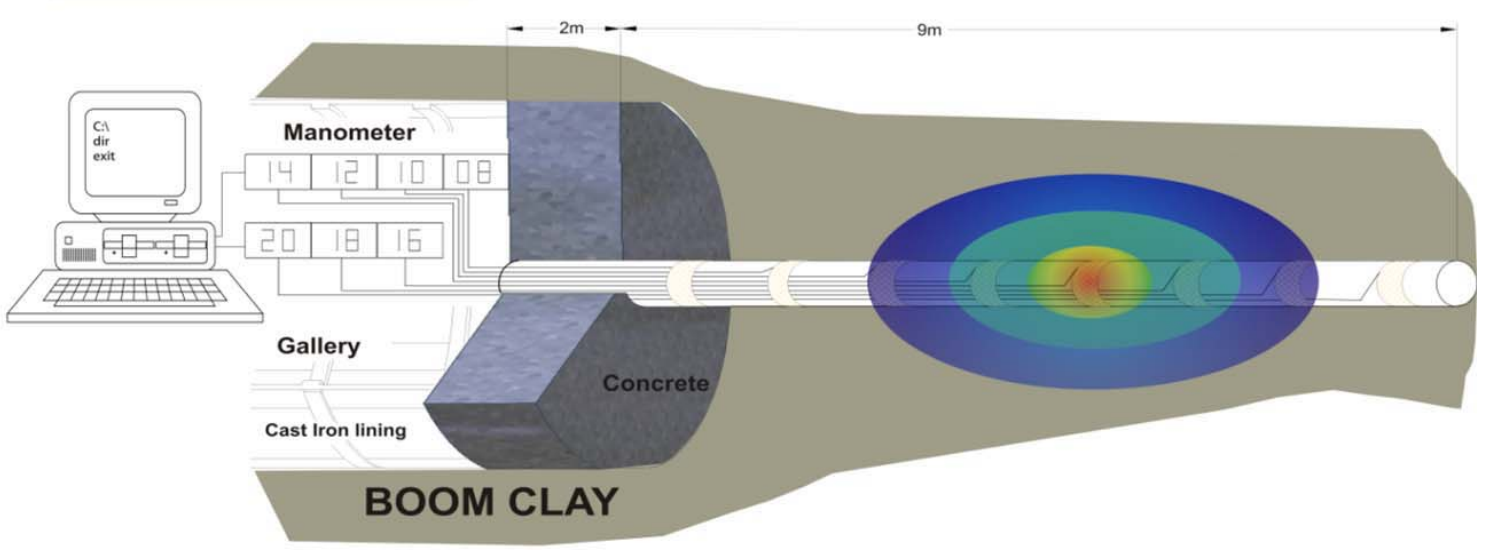

Figure 6-5. Schematic of CP1 diffusion experiment (from Maes et al., 2011) 


\subsection{Experiments at Grimsel Test Site, Switzerland}

Besides the Colloid Formation and Migration Project (Section 5), other collaborative projects being conducted at the Grimsel Test Site might be of interest to DOE/UFDC, for example the ongoing FEBEX experiment and the soon-to-begion GAST experiment (further described below). As mentioned before, the Grimsel Test Site is a URL situated in sparsely fractured crystalline host rock (http://www.grimsel.com/) in the Swiss Alps. NAGRA, which manages the GTS activities, has expressed that it would be open for UFDC scientists to participate in aspects of these experiments, without requiring formal project partnership and without asking for a "membership" fee. Also worth considering are two other GTS projects, the (1) the Long-Term Cement Studies project (Focus: EBS), which has the overall aim to increase understanding of the cement leachate interaction effects in the repository near-field and geosphere, and the (2) the Long-Term Diffusion project (Focus: NBS), which has the overall aim to provide quantitative information on matrix diffusion of radionuclides in fractured rock under in situ conditions over long time scales. The possibility of participation, and the conditions of being involved in these latter two projects, require further clarification.

\section{Full-Scale Engineered Barriers Experiment (FEBEX) (Focus: EBS, some NBS)}

The FEBEX (Full-scale Engineered Barriers Experiment) experiment is an in-situ fullscale Engineered Barrier System (EBS) test performed under natural conditions. The overall objective is to evaluate the long-term performance of the EBS and, to a lesser degree, the near-field crystalline rock, with emphasis on the thermal evolution and resaturation of bentonite backfill surrounding a heated waste package. Started in 1997, the FEBEX experiment is the longest running full-scale heater experiment in the world providing a unique data set of the transient behavior of a heated repository (http://www.cfmxchange.com/gts-phase-vi/febexe/febexe-introduction). A fixed temperature of $100^{\circ} \mathrm{C}$ has been maintained at the heater/bentonite contact during this time, while the bentonite buffer has been slowly hydrating with the water naturally coming from the rock. A total of 632 sensors of diverse types were installed in the clay barrier, the rock mass, the heaters and the service zone to measure the following variables: temperature, humidity, total pressure, displacement, pore pressure etc. Partial dismantling of the in-situ test was carried out during 2002, after five years of heating. One of the two heaters was removed and the materials recovered (bentonite, metals, instruments, etc.) have been analyzed to investigate the different types of processes undergone, while the second heater continued. The second heater has been kept in operation and will continue to do so until 2012 excavation of the second heater is planned.

\section{Gas-Permeable Seal Test (GAST) (Focus: EBS)}

The objective of the soon-to-start GAST experiments is to demonstrate the construction and performance of repository seals and plugs and to improve the understanding and the base datasets for reliably predicting water and gas transport through these sealing systems. The experiment will test a specific design option called "engineered gas transport system (EGTS)" (Figure 6-6), which involves specially designed backfill and sealing materials such as high porosity mortars or sand/bentonite $(\mathrm{S} / \mathrm{B})$ mixtures. The 
reason to develop these special designs is to allow for increased gas transport capacity (to mitigate pressure buildup from gas generation) of the backfilled underground structures without compromising the radionuclide retention capacity of the engineered barrier system. The managing organization for this experiment is NAGRA (Switzerland); a few other European partners are also involved. NAGRA has expressed that it would possibly be open for UFDC scientists to participate in aspects of the experiment.

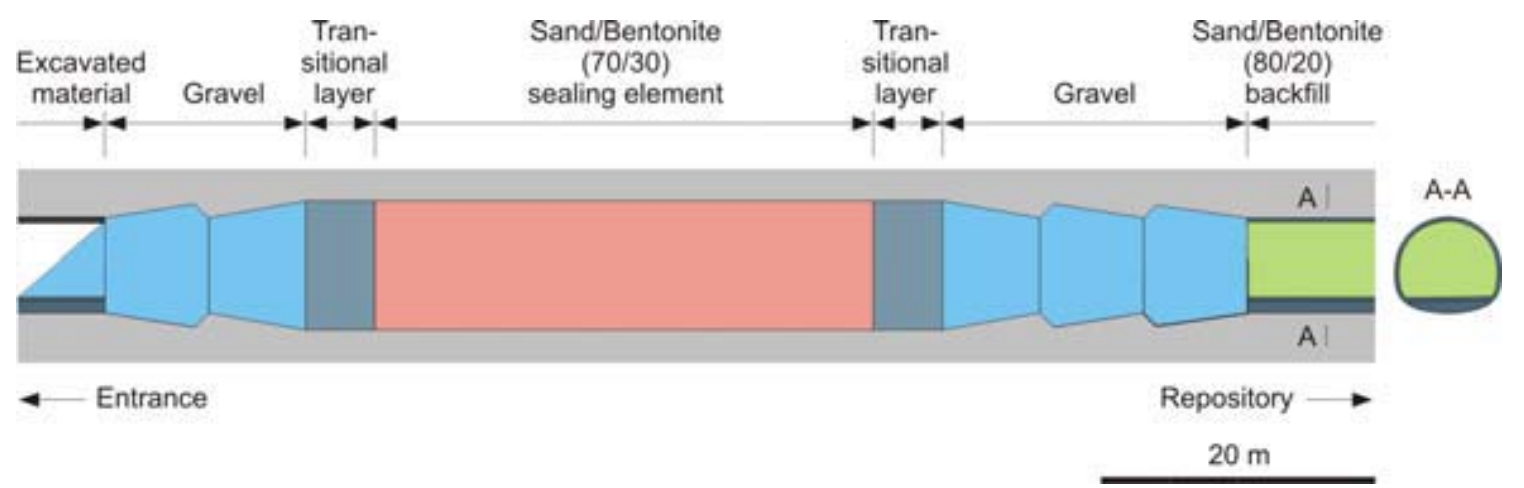

Figure 6-6. Schematic picture of repository seal design for GAST experiment (from Vomvoris, 2011)

\subsection{Experiments at Äspö Hard Rock Laboratory, Sweden}

The Äspö Hard Rock Laboratory, operated by the Swedish Nuclear Fuel and Waste Management Company (SKB), may provide another interesting option for international collaboration. Since the Swedish program has always been very active in engaging international partners, it is safe to assume that participation of DOE scientists in selected projects would be welcome. The Äspö URL consists of a main tunnel that descends in two spiral turns to a depth of 460 meters, where various tests have been and are being performed in several side galleries and niches (Figure 6-7). Of the many experiments at Äspö, we describe below two tests that might be of interest to DOE, one ongoing and one planned.

\section{Large-Scale Gas Injection Test (LASGIT) (Focus: Mostly EBS)}

This ongoing field experiment, which has been in operation for over five years, evaluates gas flow processes (related to the potential for gas generation from canister corrosion) in an unsaturated bentonite embedded in fractured crystalline rock. Current knowledge pertaining to gas flow in a compact saturated bentonite is based on small-scale laboratory studies; the LASGIT tests are designed to address specific issues relating to gas migration and its long-term effect on the hydro-mechanical performance of the buffer clay, the question of heterogeneity and tortuosity of flow paths and the possible generation of new flow paths, and the complex coupling between gas, stress, and pore-water pressure at different scales (Figure 6-8). The main organization conducting the experiment is SKB (Sweden), together with the British Geological Survey (BGS). The LASGIT experiment was initially proposed as a modeling test case for DECOVALEX-2015, but is not under 
consideration anymore. However, SKB and BGS may be open to collaboration or participation of UFDC scientists.

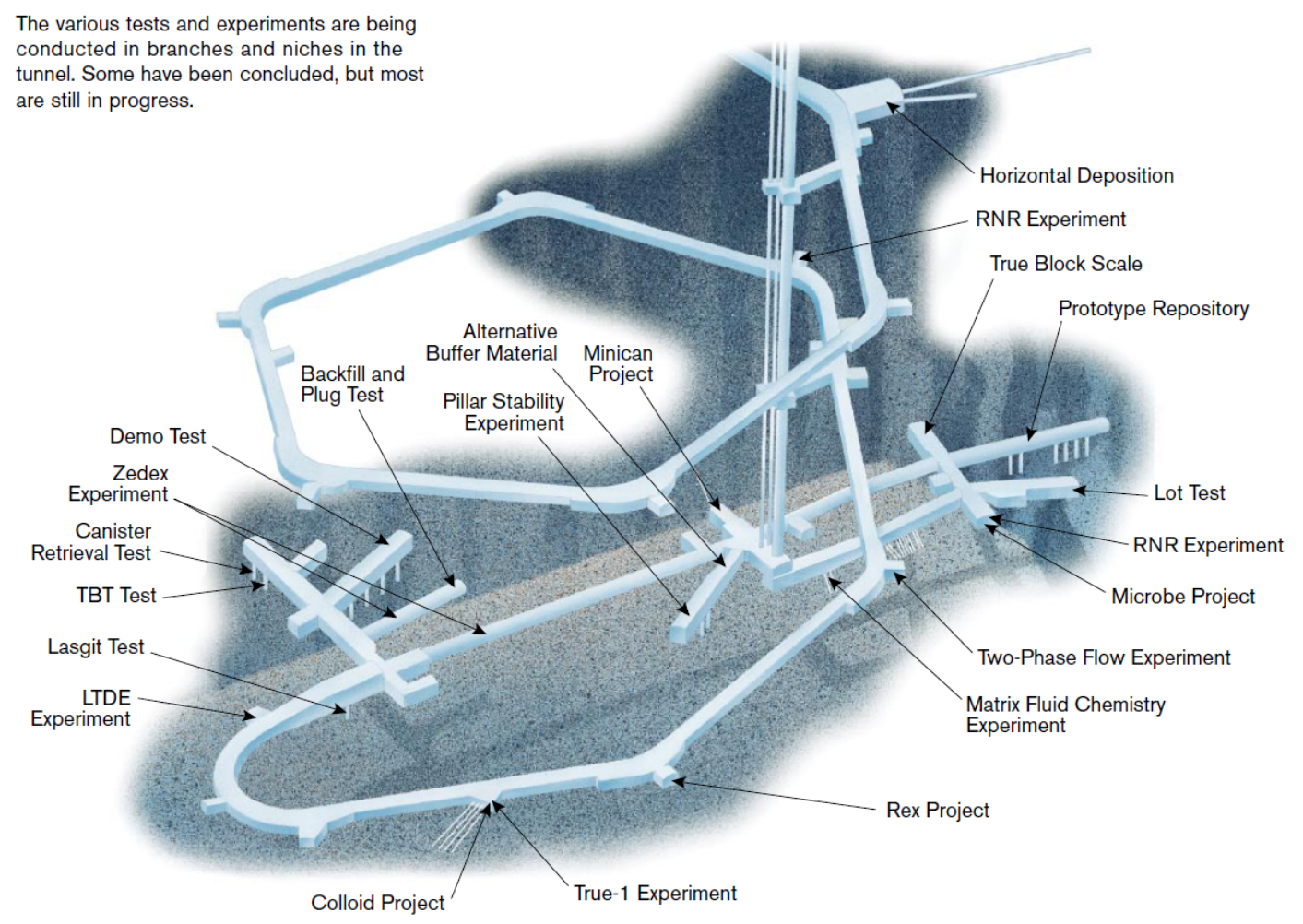

Figure 6-7. Layout of Äspö URL and location of main experiments

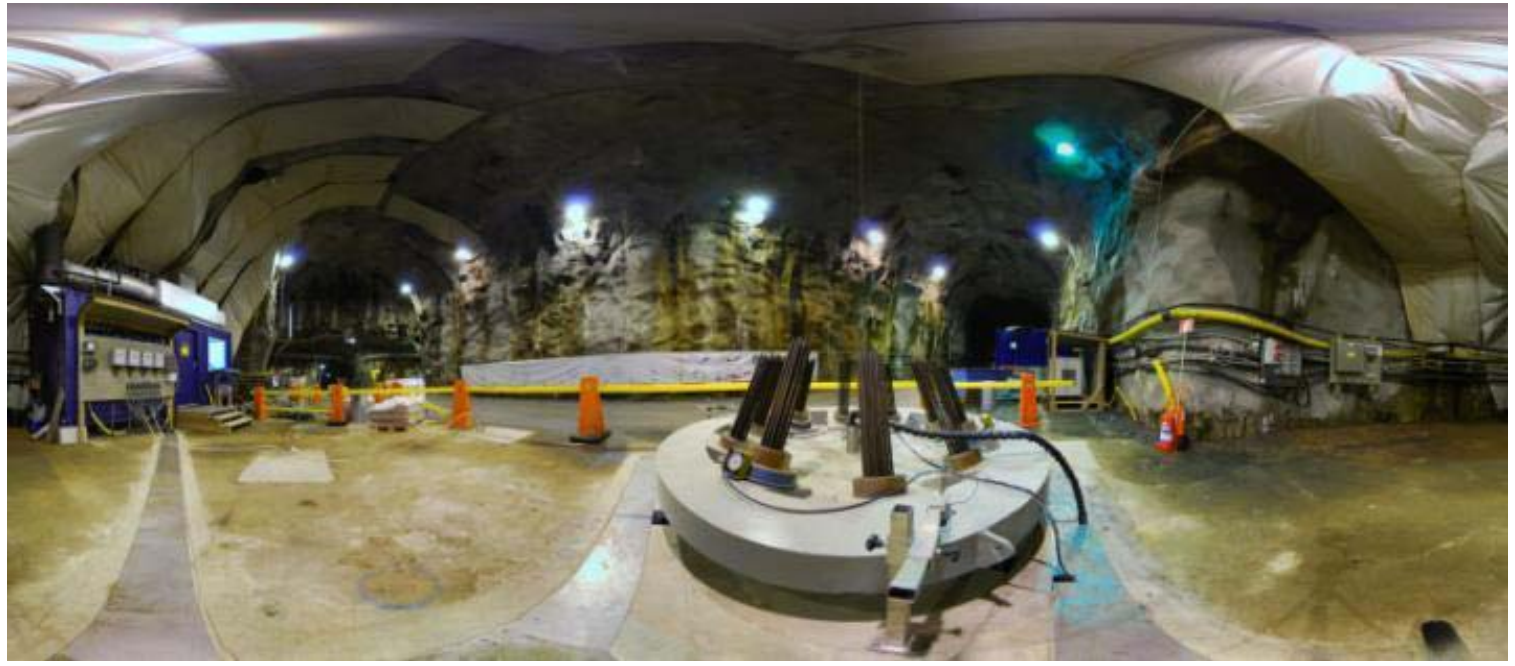

Figure 6-8. LASGIT experiment at Äspö (from Cuss, 2010) 


\section{Bentonite Rock Interaction Experiment (BRIE) (Focus: Both NBS and EBS)}

Another option for UFDC engagement may be the upcoming BRIE test to be conducted at the Äspö URL in Sweden. The main objective of this experiment is to enhance the understanding of the hydraulic interaction between the fractured crystalline rock at Äspö and unsaturated bentonite used as backfill. The setup is aligned with the Swedish concept of emplacing canisters into vertical deposition holes that are subsequently backfilled. The main organization conducting the experiment is SKB (Sweden).

\subsection{Other URL Opportunities}

Not included in this summary section are potential opportunities arising from other international URLs, see Table 2-1. Opportunities of active collaborative R\&D may exist at the two generic Japanese URLs Mizunami (crystalline rock) and Honorobe (sedimentary), at the generic Korean underground research tunnel (crystalline), and at the German Gorleben URL (salt). The latter URL had been on hold for about a decade before R\&D activities recently resumed. There are also the two URLs near Onkalo in Finland (crystalline) and near Bure in France (clay/shale); however, these are site-specific URLs at locations that are expected to eventually host a repository. The organizations for waste emplacement in Finland and France, Posiva Oy and ANDRA, respectively, are likely less inclined to open their URLs to international researchers than owners of generic URLs. Further work will be needed to explore these opportunities.

\subsection{Alternative Options for DECOVALEX, Mont Terri and CFM Participation}

As discussed in Sections 3, 4, and 5, participation in formal multinational and multipartner initiatives such as the DECOVALEX project, the Mont Terri Project and the Colloid Formation and Migration Project offer considerable benefit to DOE and UFDC. The question arises whether such benefit may also be achievable via less formal partnerships. For example, LBNL has been offered the opportunity to become one of NAGRA's modeling and analysis partners for the full-scale FE Heater experiment at Mont Terri, even if DOE would not become a formal Mont Terri partner. Similarly, scientists at Los Alamos National Laboratory (LANL) have been engaged in the Colloid Formation and Migration Project, without DOE being a full partner, and could presumably continue to do so. However, in both cases, without formal agreement, LBNL's and LANL's role would be limited to ad-hoc contributions. Full partnership, on the other hand, would give all DOE national laboratories full access to all of the many experiments that have been or will be conducted within the Mont Terri Project and CFM, respectively. Full partnership would also allow for DOE to be in a position to propose or conduct its own suite of experiments. With respect to the DECOVALEX project, participation of DOE scientists is only possible under the umbrella of a formal membership of DOE in DECOVALEX-2015; ad-hoc membership is not possible. 


\section{SUMMARY AND PATH FORWARD}

Active collaboration with international programs, initiatives, or projects is considered very beneficial to UFDC, providing access to the decades of experience that some international programs have in various disposal options and geologic environments. We postulate that increasing international engagement will help efficiently achieve UFDC's goals of conducting "experiments to fill data needs and confirm advanced modeling approaches" (by 2015) and of having a "robust modeling and experimental basis for evaluation of multiple disposal system options" (by 2020). This report discusses different opportunities of active international collaboration, with focus on both NBS and EBS aspects and those opportunities that provide access to field data (and respective interpretation/modeling) or allow participation in ongoing field experiments. It contains a concise summary of promising international opportunities, the key research gaps addressed by participating in collaborative initiatives, and the conditions, costs and benefits thereof. This summary serves as a basis for the DOE/NE-53 and UFDC planning process for FY12 and beyond.

One of the first decisions to be made by DOE/NE-53 and UFDC is about DOE's possible participation in international initiatives that require formal "membership", such as the DECOVALEX Project, the Mont Terri Project, and the Colloid Formations and Migration Project. We have therefore focused specifically on these three collaborative initiatives, described in Sections 3, 4, and 5, respectively. Once DOE has formally become a "member", any national laboratory associated with DOE would be eligible to benefit from this membership; e.g., national laboratories would have access to data generated in the past or could participate in ongoing collaborative field experiments.

In reviewing the many interesting and relevant international field studies mentioned in Sections 3 through 6, it is obvious that UFDC researchers can only engage in a small subset of many available opportunities. The staff support for active international R\&D will be covered out of the relevant UFDC work packages (e.g., EBS, NBS), and decisions on specific tasks will be made by DOE and UFDC management together with EBS and NBS representatives. Membership of DOE in the DECOVALEX, Mont Terri, and/or CFM projects provides a wide range of collaborative project options to select from. Additional opportunities are discussed in Section 6 of this report; these are field experiments conducted by international disposal programs that may be open to DOE participation without formal "membership" or long-term commitment. 


\section{REFERENCES}

Barnichon J. D. (2011) IRSN proposal - the SEALEX In Situ Tests, Presentation given at $7^{\text {th }}$ DECOVALEX 2011 workshop, April 2011, Helsinki.

Birkholzer J. T. (2011) Personal Communication.

Bossart, P., Thury, M. (2007) Research in the Mont Terri Rock laboratory: Quo vadis?, Physics and Chemistry of the Earth, Parts A/B/C, 32(1-7), pp. 19-31.

Cuss, R. (2010) Large scale gas injection test (Lasgit): Progress to May 2010, Presentation given at 6th DECOVALEX 2011 workshop, October 2010, Wuhan.

Garitte B. and others (2011) HE-E experiment - In situ Heater Test, Presentation given at $7^{\text {th }}$ DECOVALEX 2011 workshop, April 2011, Helsinki.

Garitte B. (2010) New In Situ Experiments at Mont Terri, Presentation given at 6th DECOVALEX 2011 workshop, October 2010, Wuhan.

Hokr M. and Slovak J. (2011) Bedrichov Tunnel test case proposal for DECOVALEX 2015, Presentation given at $7^{\text {th }}$ DECOVALEX 2011, April 2011, Helsinki.

Jing L. and Hudson J.A. (2011) Potential Tasks for the Next DECOVALEX Phase 20122015, Internal DECOVALEX Report, May 16, 2011.

Jove-Colon, C.F., Caporuscio, F.A., Levy, S.S., Xu, H., Blink, J.A., Halsey, W.G., Buscheck, T., Sutton, M., Serrano de Caro, M.A., Wolery, T.J., Liu, H.H., Birkholzer, J.T., Steefel, C.I., Rutqvist, J., Tsang, C.F., Sonnenthal, E. (2010), Disposal Systems Evaluations and Tool Development - Engineered Barrier System (EBS) Evaluation, U.S. DOE Used Fuel Disposition Campaign, September 2010.

Li X. (2011) Design and Status of the PRACLAY Seal and Heater Test, Presentation given at HADES Workshop, May 2011, Antwerp.

Maes N., Weetjens E., Aertsen M., Govaerts J., and Van Ravestyn L. (2011) Added Value and Lessons Learned from In-Situ Experiments - Radionuclide Migration, Presentation given at HADES Workshop, May 2011, Antwerp.

Nutt M. (2010) Used Fuel Disposition Campaign International Activities Implementation Plan, (FCR\&D-USED-2011-000016 REV 0), U.S. DOE Used Fuel Disposition Campaign.

Nutt M. (2011) Used Fuel Disposition Campaign Disposal Research and Development Roadmap, (FCR\&D-USED-2011-000065 REV0), U.S. DOE Used Fuel Disposition Campaign.

Polak A., Elsworth D., Yasuhara H., Grader A. S., and Halleck P. M. (2003) Permeability reduction of a natural fracture under net dissolution by hydrothermal fluids, Geophys. Res. Lett., 30(20), 2020.

Reimus P. (2011) Personal Communication.

Rejeb A. and Cabrera J. (2006) Time-dependent evolution of the excavation damaged zone in the argillaceous Tournemire Site (France), Proceedings "GeoProc 2006," 
Invited lecture in the 2nd International Conference on Coupled THMC Processes in Geosystems and Engineering, May 22-25 2006, Nanjing, China, pp. 65-74.

Rutqvist J. and Min, K.-B. (2011) THMC Modeling of Rock Fractures, Presentation given at $7^{\text {th }}$ DECOVALEX 2011 workshop, April 2011, Helsinki.

Tsang C.-F., Stephansson O., Jing L., and Kautsky F. (2009) DECOVALEX Project: from 1992 to 2007, Environmental Geology, 57, 1221-1237, 2009.

Tsang C.-F., Barnichon J. D., Birkholzer J. T., Li X. L., Liu H. H., Sillen X., and Vietor T. (2011) A Review of Coupled Thermo-Hydro-Mechanical Processes in the Nearfield of a High-Level Radioactive Waste Repository in a Clay Formation, submitted to International Journal of Rock Mechanics and Mining Sciences, in review.

Van Marcke P. and Bastiaens W. (2010) Construction of the PRACLAY Experimental Gallery at the Hades URF, Clay in Natural and Engineered Barriers for Radioactive Waste Confinement, 4th International Meeting, March, 2010, Nantes, France.

Vietor T., Polster M., Garitte B., and Martin, D. (2011) Mine-by test in the Mont Terri rock laboratory - MB Experiment, Presentation given at $7^{\text {th }}$ DECOVALEX 2011 workshop, April 2011, Helsinki.

Vietor, T. (2011) Personal Communication.

Vomvoris S. (2011) Personal Communication.

Wang Y. (editor) (2010) Natural System Evaluation and Tool Development - FY10 Progress Report, U.S. DOE Used Fuel Disposition Campaign, August 2010.

Yasuhara H., Elsworth D., and Polak A. (2004) The evolution of permeability in a natural fracture: significant role of pressure solution, J. Geophys. Res., Vol. 109.

Zuidema P. (2007) Advancements in Deep Geological Disposal of Radioactive Waste through International Cooperation: The Role of Underground Laboratories - Mont Terri Project, Proceedings of the 10 Year Anniversary Workshop, pp 69-71, Rep. Swiss Geol. Surv. 2. 


\section{DISCLAIMER}

This document was prepared as an account of work sponsored by the United States Government. While this document is believed to contain correct information, neither the United States Government nor any agency thereof, nor The Regents of the University of California, nor any of their employees, makes any warranty, express or implied, or assumes any legal responsibility for the accuracy, completeness, or usefulness of any information, apparatus, product, or process disclosed, or represents that its use would not infringe privately owned rights. Reference herein to any specific commercial product, process, or service by its trade name, trademark, manufacturer, or otherwise, does not necessarily constitute or imply its endorsement, recommendation, or favoring by the United States Government or any agency thereof, or The Regents of the University of California. The views and opinions of authors expressed herein do not necessarily state or reflect those of the United States Government or any agency thereof or The Regents of the University of California.

Ernest Orlando Lawrence Berkeley National Laboratory is an equal opportunity employer. 